\title{
Heavy minerals from sedimentary rocks of the Malcov Formation and their palaeogeographic implications for evolution of the Magura Basin (Western Carpathians, Slovakia) during the Late Eocene-Late Oligocene
}

\author{
Katarína BÓNOVÁ ${ }^{1, *}$, Ján BÓNA², Martin KOVÁČIK³ and Dušan LAURINC ${ }^{4}$ \\ 1 Pavol Jozef Šafárik University in Košice, Institute of Geography, Faculty of Science, Jesenná 5, 04001 Košice, Slovak Re- \\ public \\ 2 Kpt. Jaroša 13, 04022 Košice, Slovak Republic \\ 3 State Geological Institute of Dionýz Štúr, Regional centre - Košice, Jesenského 8, 04001 Košice, Slovak Republic \\ 4 State Geological Institute of Dionýz Štúr, Mlynská dolina 1, 81704 Bratislava, Slovak Republic
}

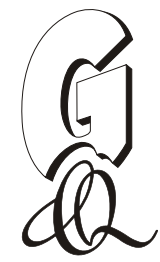

\begin{abstract}
Bónová, K., Bóna, J., Kováčik, M., Laurinc, D., 2016. Heavy minerals from sedimentary rocks of the Malcov Formation and their palaeogeographic implications for evolution of the Magura Basin (Western Carpathians, Slovakia) during the Late Eocene-Late Oligocene. Geological Quarterly, 60 (3): 675-694, doi: 10.7306/gq.1285

Detrital heavy minerals separated from the Malcov Fm. deposits (Magura Nappe) indicate their source rocks and areas. The heavy mineral assemblages predominantly consist of garnet, zircon, tourmaline, rutile and Cr-spinel. EPMA analyses reveal a few groups of garnets: zoned and unzoned Grs almandines, Prp-Sps almandines, unzoned Prp almandines, almandines, Sps almandines and rare zoned spessartine grains ( $>5 \mathrm{~mol} \% \mathrm{Sps}$ ). The garnet composition indicates that gneisses, mica schists, amphibolites and granites were their main source rocks, but low-grade metapelites with Mn mineralisation probably contributed as well. The detrital dravitic tourmalines were mostly derived from paragneisses and mica schists. Cr-spinel indicates a volcanic source. Based on heavy mineral assemblages, coupled with palaeoflow analysis, we conclude that the Marmarosh Massif and Fore-Marmarosh Suture are the most probable source areas. Aditionally, the Malcov sedimentary basin was supplied by material from the crystalline complexes of the Tisza Mega-Unit and Pieniny Klippen Belt (PKB). The bulk of the clastic deposits comprise classical turbidites. These lithofacies were deposited from either turbidity currents or from concentrated density flows. The palaeoflow record is varied and highlights the contribution of sedimentary material from several directions and/or diversion of gravity currents from the main flow direction (SE-NW). The marginal parts of the Malcov sub-basins were formed of deformed and uplifted older formations of surrounding units of the Magura Nappe and PKB (submerged ridges). Older (Late Cretaceous to Eocene) flysch sediments may have been redeposited from these ridges to neighbouring sub-basins in a transverse direction (NE-SW).
\end{abstract}

Key words: Western Carpathians, Magura Nappe, Malcov Formation, provenance, heavy minerals, mineral composition.

\section{INTRODUCTION}

The analysis of heavy minerals is a widely used tool in provenance reconstruction of ancient and modern clastic sedimentary rocks (e.g., Morton, 1984, 1987; Morton and Hallsworth, 1994, 1999; Morton et al., 2005). Heavy minerals, such as garnet, tourmaline, zircon and Cr-spinel, are resistant to weathering, mechanical effects of transport and diagenesis. They usually resist intrastratal dissolution, as well. Their chemical composition is generally dependent on the parent rock composition temperature and pressure conditions under which they originated (magmatic, postmagmatic/hydrothermal or metamorphic

* Corresponding author, e-mail: katarina.bonova@upjs.sk Received: October 30, 2015; accepted: February 17, 2016; first published online: March 21, 2016 processes) and therefore heavy minerals are good provenance indicators, and provenance data can then be used in palaeogeographic reconstructions.

Heavy mineral assemblages have been successfully used in sedimentary research of the External Western Carpathians. The use of heavy mineral associations for the interpretation of source areas in the Flysch Belt of the Western Carpathians was exploited by Leško et al. (1959), Starobová (1962), Ďurkovič (1965, 1966), Koráb and Duurkovič $(1966,1973)$ and Fejdiová (1990); more decisive results were obtained by using the electron probe combined with optical methods (Otava et al., 1997, 1998; Salata and Oszczypko, 2000; Salata, 2002a, b, 2004, 2013, 2014a, b; Oszczypko and Salata, 2004, 2005; Grzebyk and Leszczyński, 2006; Bónová et al., 2009a, b, 2010a, b; Salata and Uchman, 2012, 2013).

In this article we deal with the Malcov Formation deposits from the Rača and Krynica tectono-lithofacies units of the Magura Nappe, providing brief lithological and petrographic characteristics, and the chemical compositions of selected heavy minerals in order to indicate the source rock, as well as 


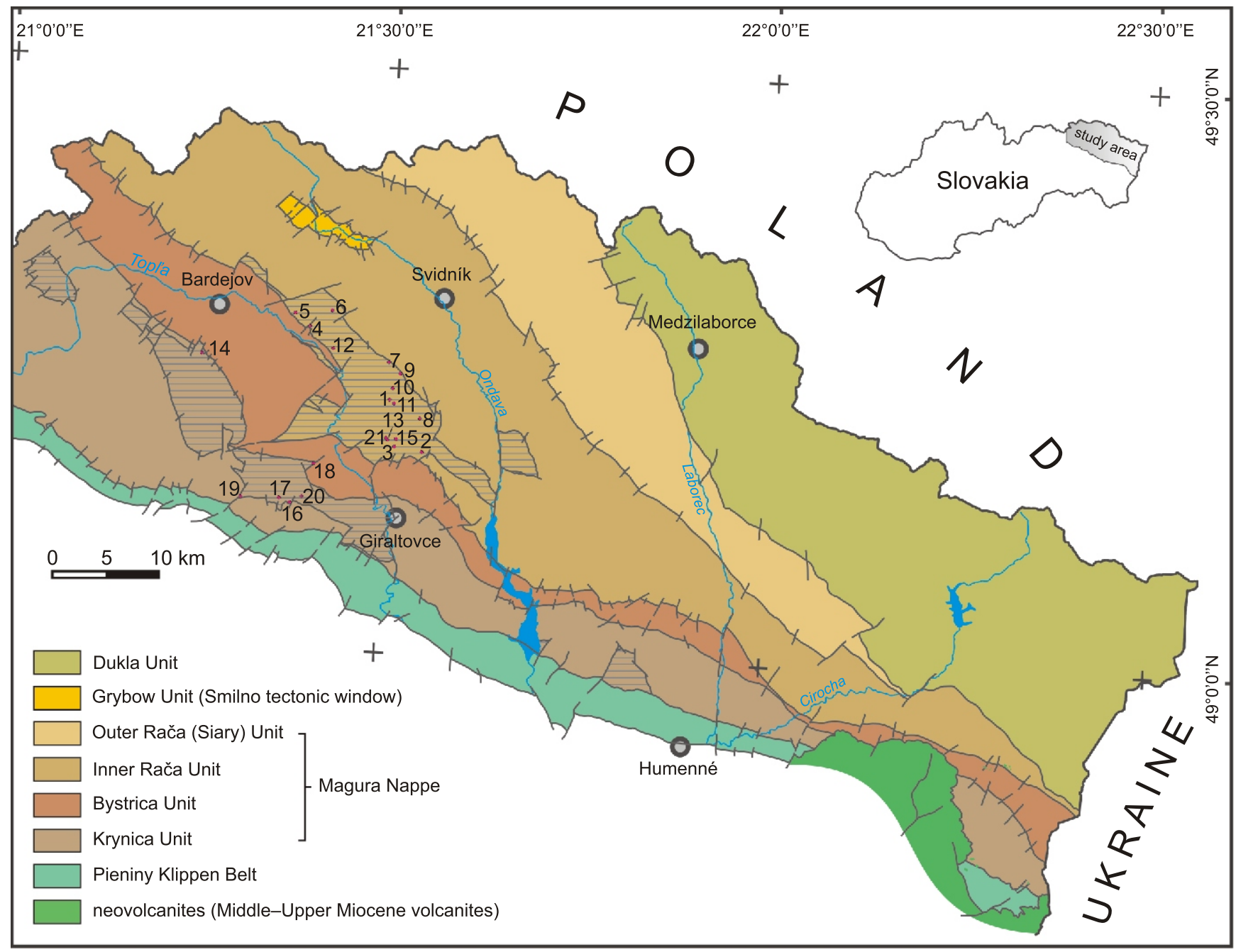

Fig. 1. Simplified and partly modified structural sketch map of the NE part of the Slovak Flysch Carpathians (according to Stránik, 1965; Koráb, 1983; Nemčok, 1990; Žec et al., 2006; Kováčik et al., 2011; Geological map..., 2013) with sampling locations

The numbers correspond to the marked samples in Appendix 1*; horizontal pattern shows the occurrence of the Malcov Fm.

analysis of the depositional environment. This study uses heavy mineral analysis to better locate the sediment sources supplying the Malcov Basin. The results of petrographic-mineralogical research of these deposits, supplemented by palaeoflow analysis, are additional tools for the identification of source areas.

\section{GEOLOGICAL SETTING}

This study analyses the provenance and sedimentology of the youngest fill (Potfaj et al., 2008; Kováčik et al., 2011) of the Magura Basin, which is represented by Malcov Formation, situated in the western part of the Nízke Beskydy Mts. outcropping in the northeastern part of Slovakia (Fig. 1).

The Malcov beds were distinguished from the Richvald "series" by Świdziński (1961). Later the term Malcov Formation was used (Leško and Samuel, 1968). The Malcov Fm. is widespread within NE Slovakia - Nízke Beskydy and the Čergov Mts. (cf. Nemčok, 1961, 1990; Nemčok and Koráb, 1963;
Stránik, 1965; Leško and Samuel, 1968; Nemčok et al., 1990). Its occurrence is also known from the Polish part of the Flysh Carpathians, southwards from Nowy Sącz (Oszczypko, 1973), near Nowy Targ (Cieszkowski and Olszewska, 1986) and the village of Leluchów (Blaicher and Sikora, 1967). Potfaj (1983) and Potfaj et al. (1991) described the Malcov Fm. within the Oravská Magura Mts. The occurrence and continuation of the Malcov Fm. is shown on the Geological Map of the Western Carpathians and adjacent areas (Lexa et al., 2000).

According to recent work on the region (Kováčik et al., 2011, 2012), the Malcov Fm. is an integral part of the Krynica and Rača tectono-lithofacies units. Both units, together with the Bystrica Unit, form the Magura Nappe of the Flysch Belt adherent to the Outer Western Carpathians (e.g., Lexa et al., 2000). The lithological content of these units consists of the deep-sea, mostly siliciclastic deposits of Late Cretaceous to Oligocene age. In the south, the Magura Nappe is tectonically bounded by the Pieniny Klippen Belt, while in the north-east it is in tectonic contact with the Dukla Unit belonging to the Fore-Magura group of nappes. The Grybow Unit, as the innermost unit of the 
Fore-Magura group of nappes, crops out in the Smilno tectonic window beneath the Inner Rača Unit (Fig. 1).

The Rača Unit represents the northernmost tectono-lithofacies unit of the Magura Nappe in the area investigated. On the basis of lithofacies differences in its northern and southern parts, two zones are distinguished - an external (Outer Rača Unit, equivalent to the Siary Unit in Poland) and an internal (Inner Rača Unit, Rača Unit s.s. in Poland) in terms of the current geological map of the region at 1:50,000 scale (Kováčik et al., 2011). In view of this division, the Malcov Fm. is a part of the Inner Rača Unit, where it is the main building block of the Brezovka and Olšava synclinoria (cf. Bóna et al. in Kováčik et al., 2012). The Inner Rača Unit is built of the following formations (Fig. 2): the Kurimka Fm. (sensu Samuel, 1990), the Beloveža Fm., the Zlín Fm. and the Malcov Fm. The Outer Rača Unit has a narrower stratigraphic range and consists of the Beloveža and Zlín formations (Kováčik et al., 2011, 2012).

The Bystrica Unit is overthrusted on the Inner Rača Unit to the north. In the south, it is in tectonic contact with the Krynica Unit. The lithostratigraphy of the Bystrica Unit is similar to the Outer Rača Unit, the older Beloveža Fm. being overlain by the Zlín Fm.

The Krynica Unit is the southernmost tectono-lithofacies unit of the Magura Nappe in the area studied and consists of the Proč, Čergov, Strihovce and Malcov fms. The Proč Fm. is commonly regarded as a part of the PKB (e.g., Nemčok, 1990; Lexa et al., 2000). However, later research in the study area showed a facies transition (Jasenovce Member) between the Proč and Strihovce fms. and so both formations constitute an integral part of the Krynica Unit (Potfaj in Žec et al., 2006; Žec et al., 2011).

The stratigraphic range of the Malcov Fm. is Late Eocene to Late Oligocene. The thickness of the strata in the Krynica Unit is considerably greater (approximately 1500-2000 m) than in the Rača Unit (about 800-1200 m) and its deposition began earlier in the older part of the Late Eocene (nannoplankton zone NP18), while in the Rača Unit this occurred at the Eocene-Oligocene boundary (zone NP21). The deposition of the formation lasted at least until the Late Oligocene (zone NP24, Kováčik et al., 2012; Fig. 2). The Late Oligocene age of the Malcov Fm. was also confirmed in the Polish part of the Magura Nappe (nannoplankton zones NP24 and NP25, Oszczypko-Clowes, 2001).

The Malcov Fm. of the Rača Unit grades from older strata of the Zlín Fm. (with interbedding of both formations' lithofacies in the northern part of the Inner Rača Unit in the Early Oligocene), whereas in the Krynica Unit, it is developed in the overlapping of the Strihovce Fm. - in the region studied as a part of Raslavice and Richvald synclinoria. The lithofacies infills of the Malcov $\mathrm{Fm}$. are similar in both units. Its dominant and main facies is represented by grey calcareous claystones and siltstones with interbeds of quartzose-carbonate sandstones (flysch facies) This facies has a classic flysch character. There are a number of other, subordinate lithostratigraphic units (or facies) of relatively large stratigraphic significance. At the bottom of the formation, the Globigerina Marls are present (Leluchów Marl Member in the Polish part of the Magura Nappe, cf. Birkenmajer and Oszczypko, 1989), together with variegated claystones, laminated Tylawa limestones and the oldest part of the Menilite Member. This member (hard dark brown quartzose "menilite" shales, pelocarbonates, calcareous claystones and sandstones; Smereczek Shale Member in the Polish part of the Magura Nappe, cf. Birkenmajer and Oszczypko, 1989) is present at two younger stratigraphic levels. Compared with the Menilite Mb. of outer units of the Flysch Belt (Grybów or Dukla units), the absence of black cherts - menilites - is characteristic of their lithology. A coarse-grained, sandstone-conglomerate facies is locally also present - it forms one part of the Malcov
Fm. of the Inner Rača Unit and about four levels are developed in the Krynica Unit.

The dominant Malcov Fm. palaeoflow direction from SE to NW was documented by Koráb et al. (1962), Ďurkovič (1966), Leško and Samuel (1968), Nemčok and Ďurkovič (1989), Oszczypko (2006) and Oszczypko and Oszczypko-Clowes (2009).

In terms of provenance, acid igneous rocks and metamorphic rocks coupled with carbonates are regarded as source rocks for the Malcov deposits (Koráb et al., 1962; Nemčok and Durkovič, 1989). The carbonates were derived from the Pieniny Klippen Belt (Koráb et al., 1962; Ďurkovič, 1966; Nemčok and Durkovič, 1989; Olszewska and Oszczypko, 2010), rocks of crystalline basement origin were supplied by "the source area situated in the South" (Koráb et al., 1962) or by "multipoint source areas" (Oszczypko and Oszczypko-Clowes, 2009).

\section{MATERIAL AND ANALYTICAL METHODS}

Sedimentological data were acquired through investigation of the successions and by the geological mapping. The sedimentary successions were investigated bed by bed. Lithofacies were specified on the basis of grain size, bed thickness and geometry, sedimentary structures and textures, as well as composition (sensu Pickering et al., 1986). Depositional environments were interpreted using lithofacies associations. Data on the direction and orientation of sedimentary structures of the lower bed surfaces are also important to the provenance analysis. Palaeoflow direction indicators were corrected with respect to the tilted bed surfaces, which were restored into a horizontal position.

Samples from the sandstone-conglomerate, flysch and menilite facies of Rača and Krynica units were evaluated by petrographic (modal composition) and petrofacies methods. For the Rača Unit, we have analysed 15 samples from flysch facies, 2 samples from menilite facies and 3 from sandstone-conglomerate facies. For the Krynica Unit, 4 samples were taken from flysch, 1 sample from menilite and 7 samples from sandstone-conglomerate facies.

Heavy mineral associations and the chemical composition of selected minerals were investigated for 4 clastic sedimentary samples: 2 samples from the Rača Unit (Štefurov and Okrúhle localities) and 2 from the Krynica Unit (Klušov and Koprivnica localities).

Samples weighing 5-10 kg were collected for the preparation of heavy mineral concentrates. Preparation of the samples was carried out in the laboratories of the Department of Applied Technology of Raw Minerals (State Geological Institute of Dionýz Štúr - Regional centre Košice, Slovak Republic). Heavy mineral concentrates were obtained using the standard methods, from the 0.025 to $0.063 \mathrm{~mm}$ size fraction and by final separation in heavy liquid (tribromomethane with $D=2.89 \mathrm{~g} / \mathrm{cm}^{3}$ ). Concentrates were qualitatively and quantitatively evaluated with a focus on the translucent heavy minerals. Totals of 350 to 400 grains were optically evaluated.

Garnet, tourmaline and $\mathrm{Cr}$-spinel were analysed in polished thin sections using an electron microanalyzer CAMECA SX 100 (State Geological Institute of Dionýz Štúr, Bratislava, Slovak Republic) with the WDS method at accelerating voltages of $15 \mathrm{kV}$, beam current of $20 \mathrm{nA}$ and electron beam diameter of $5 \mu \mathrm{m}$. To measure concentrations of various elements the following natural and synthetic standards were used: fluorapatite $(\mathrm{PK} \alpha)$, orthoclase $(\mathrm{SiK} \alpha), \mathrm{TiO}_{2}(\mathrm{TiK} \alpha), \mathrm{Al}_{2} \mathrm{O}_{3}(\mathrm{AlK} \alpha), \mathrm{Cr}(\mathrm{CrK} \alpha)$, fayalite $(\mathrm{FeK} \alpha)$, rhodonite $(\mathrm{MnK} \alpha)$, forsterite $(\mathrm{MgK} \alpha)$, wollastonite $(\mathrm{CaK} \alpha), \mathrm{SrTiO}_{3}(\mathrm{SrK} \alpha)$, albite $(\mathrm{NaK} \alpha), \mathrm{LiF}(\mathrm{FK} \alpha)$ and $\mathrm{NaCl}(\mathrm{CIK} \alpha)$. Chemical data of detrital garnets were taken 

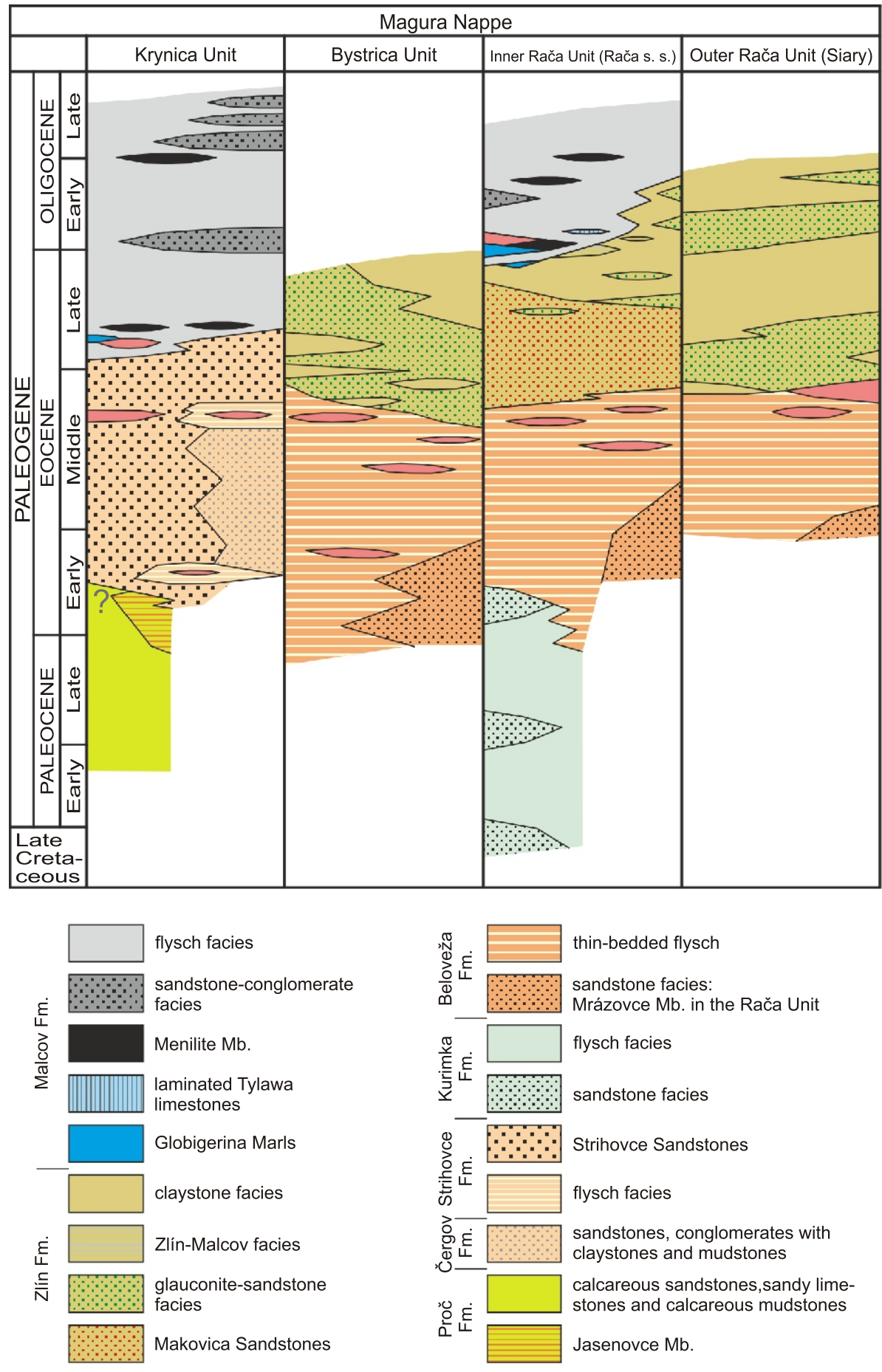

Malcov, Beloveža and Strihovce Fms.

variegated mudstones

Fig. 2. Litostratigraphy of the Magura Nappe in the Nízke Beskydy Mts. and adjacent areas (compiled after Kováčik et al., 2012; Potfaj in Žec et al., 1997; Žec et al., 2011 and Nemčok et al., 1990) 
from the BZK-322a and BZK-208 samples (Rača Unit) and from the BZKo-765 and MF-1 samples (Krynica Unit). Crystallochemical formula of garnet was normalized to 12 oxygens and conversion of iron valence $\left(\mathrm{Fe}^{3+}\right.$ and $\left.\mathrm{Fe}^{2+}\right)$ according to ideal stoichiometry. Analysed points for tourmaline (BZK-322a, BZK-208 and MF-1 samples taken from the Rača and Krynica units, respectively) were located in the centre, on the core-rim and on the rim of the grains. Tourmaline structural formula was calculated on the basis of 31 oxygens, $(\mathrm{OH}+\mathrm{F})=4$ a.p.f.u., $\mathrm{B}=3$ a.p.f.u. Chemical data of $\mathrm{Cr}$-spinel grains were obtained from BZK-322a (Rača Unit) and BZKo-765 (Krynica Unit) samples. Analyses of spinel were calculated on the basis of 3 cations. $\mathrm{Fe}^{2+}$ and $\mathrm{Fe}^{3+}$ in spinel were allocated according to the ideal stoichiometry. Cathodoluminescence was used for observation of the zircon zoning. It was carried out in the same instrument at accelerating voltage of $8 \mathrm{kV}$ and a beam current of $1 \times 10^{-3} \mathrm{nA}$.

\section{RESULTS}

\section{SEDIMENTOLOGY}

The bulk of the flysch facies has the character of classic turbidites (lithofacies D2.1, C2.1, C2.2 and C2.3, sensu Pickering et al., 1986). Thin to thick-bedded sandstone-mudstone (C2.1 to C2.3) or siltstone-mudstone (D2.1) couplets generally show normal grading with partial or complete Bouma sequences (Ta-Te, sensu Bouma, 1962). The most common sole structures are flute, prod and groove casts. These lithofacies were deposited from turbidity currents or concentrated density flows (sensu Mulder and Alexander, 2001) and shaped as flat laminar bodies formed especially in the middle and distal parts of submarine lobes and in the spaces between them.

Locally, thick to very thick beds of greywacke quartz-carboniferous sandstone, overlain by very thick layers of grey calcareous silty claystone (lithofacies C2.4, sensu Pickering et al., 1986), are present. The sandstone-mudstone couplets commonly reach up to $5 \mathrm{~m}$ in thickness. Sandstone beds have a typical composite lamination with alternation of ripple-cross, sinusoidal and parallel lamination in a vertical direction. The internal structures may show different flow directions. This lithofacies originated from large-volume concentrated gravity currents, which were reflected or deflected from the flow direction on the edges of sub-basins.

The sandstone-conglomerate facies consists of several $10 \mathrm{~m}$ thick bed successions within the flysch facies of the Malcov Fm. We have observed several lithofacies (sensu Pickering et al., 1986): lithofacies A2.4 - a very thick to thick-bedded, clast-supported conglomerate is commonly normally graded to stratified pebbly sandstone, lithofacies A2.8 - a normally graded pebbly sandstone usually overlain by stratified (ripple-cross, sinusoidal and parallel lamination) granule sandstone, lithofacies B1.1 - thick to medium-bedded massive sandstones, lithofacies B1.2 - thin-bedded massive sandstones and lithofacies C2.1 - thick-bedded sandstone-mudstone couplets with well-developed Bouma intervals, mostly $\mathrm{Tac}(\mathrm{d}) \mathrm{e}, \mathrm{Ta}(\mathrm{d}) \mathrm{e}, \mathrm{Tbc}(\mathrm{d}) \mathrm{e}$. The lithofacies distinguished originated mostly from concentrated density flows in channels or in transition zones between channels and lobes. Deposition from turbidity currents was of minor importance in this case.

The most common coarser-grained clastic lithofacies associated with Menilite-type black shales are thin to medium-bedded very fine-grained sandstones and siltstones (Tcd, Td) nor- mally graded to thin to thick-bedded grey calcareous mudstones (lithofacies C2.2, C2.3 and D2.1 sensu Pickering et al., 1986). The deposition of these lithofacies was from turbidity currents.

Flute and groove casts are the most important sedimentary structures for the palaeoflow analysis (Fig. 3B). They are usually present on the bases of the sandstone layers belonging mainly to lithofacies class $\mathrm{C}$. The palaeoflow record is very varied and highlights the contribution of sedimentary material from several directions and/or diversion of gravity currents from the main flow direction. Besides the dominant flow direction from SE to NW (longitudinal direction, Fig. 3), transverse input of clastics is also of great significance. We have recorded three other important palaeoflow directions (Fig. 3A): (1) from $S$ and SW to $\mathrm{N}$ and NE (mainly in the Krynica Unit), (2) from E and NE to W and SW (mostly in the Rača Unit), (3) from NW to SE (Iocally observed in both units).

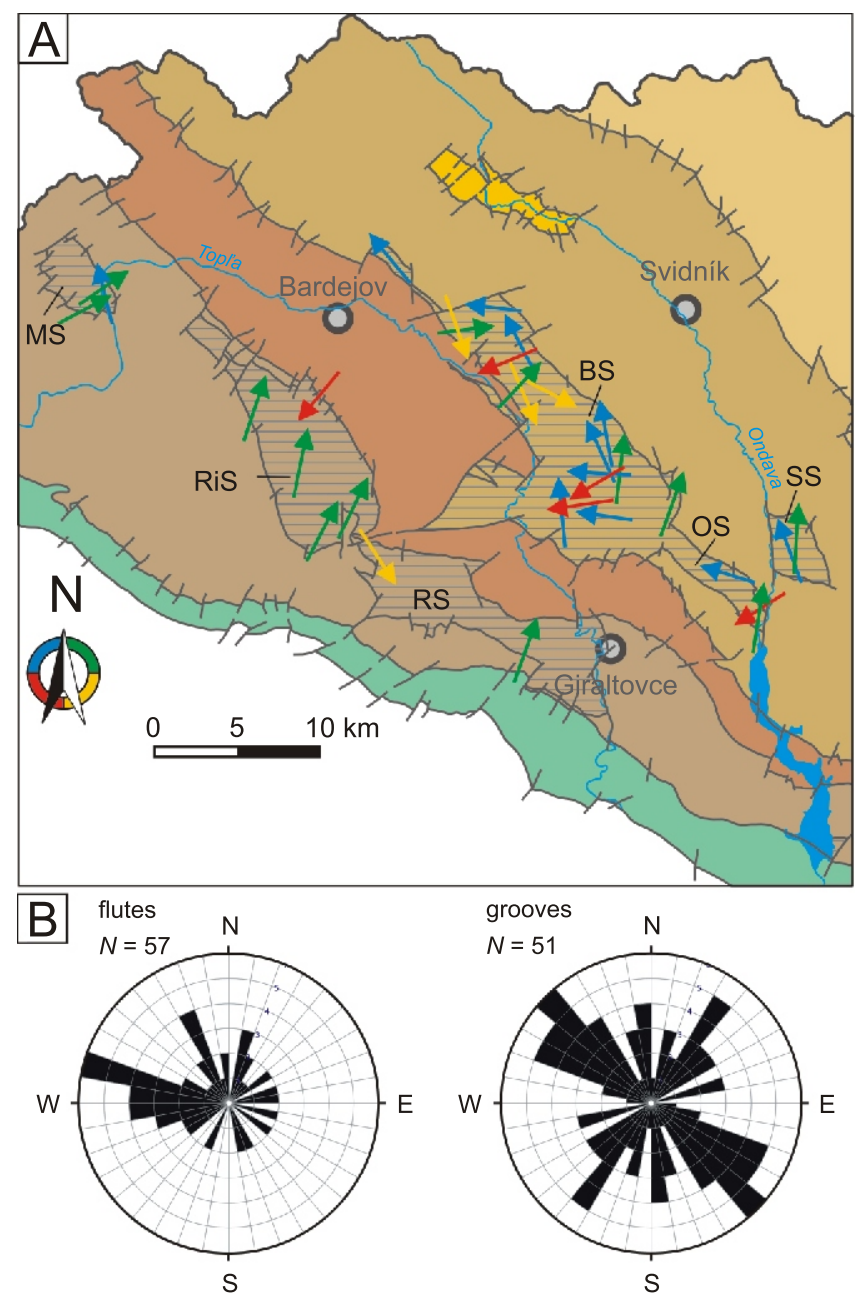

Fig. 3A - geological map showing the main palaeocurrent trends in the Malcov Fm. deposits (compiled after Koráb et al., 1962; Stránik, 1965; Nemčok and Ďurkovič, 1989 and our data); B - rose diagrams with palaeocurrent trends in the Brezovka and Olšava synclinoria

BS - Brezovka synclinorium, OS - Olšava synclinorium, SS - Sitník syncline, MS - Malcov syncline, RiS - Richvald synclinorium, RS Raslavice synclinorium; horizontal pattern shows the occurence of Malcov Fm.; other explanations as in Figure 1 
PETROGRAPHY (AND DETRITAL MODES)

The results of detrital mode investigations of the Malcov Fm. deposits are given in Appendix 1.

For the Rača Unit, the flysch facies is represented by sublitharenites and rarely by lithic greywackes (Fig. 4; Pettijohn et al., 1972). They are medium- to coarse-grained, poorly to better sorted, angular to subangular. Monocrystalline quartz dominates over polycrystalline quartz $(\mathrm{Qm} / \mathrm{Qp}=2.31-6.40)$ in samples. Grains tend to be slightly rounded, but angular clasts are also present. Sericitised plagioclase is found more often than K-feldspar, the ratio Plg/Kfs varying from 1.09 to 1.44 (rarely 3), sporadically vice-versa $(\mathrm{Plg} / \mathrm{Kfs}=0.86)$. Clastogenic micas are represented by chloritised, baueritised biotite and muscovite. Muscovite prevails over biotite. The accessory mineral assemblage comprises detrital (rounded and euhedral) zircon, detrital and acicular tourmaline, rutile, spinel, glauconite and framboidal pyrite (especially near the fossils). Lithic fragments are moderately common: limestones (micritic and sparitic), sandstones, phyllites, mica schists, gneisses, granitoids, volcanic rocks (also volcanic glass). The binding material is formed by sparitic cement (somewhere up to 19\%) and matrix.

Unlike the flysch facies, the sandstone-conglomerate facies contains sublitharenites and lithic greywackes (Fig. 4; Pettijohn et al., 1972) with slightly dominant polycrystalline quartz $(\mathrm{Qm} / \mathrm{Qp}=0.61-0.92)$. Clastogenic plagioclase and K-feldspar occur almost in identical amounts (Plg/Kfs $=1-1.17$ ). The matrix, which is formed from fine quartz aggregates and clay minerals (up to $20 \%$ ), prevails over sparitic cement. As well as the lithic fragments noted above, basic rocks are also present.

The menilite facies is represented by fine- to medium-grained arenites (sublitharenites sensu Pettijohn et al., 1972; Fig. 4A). The predominant monocrystalline quartz shows corrosion signs. Feldspar fragments are altered to sericite and clay minerals. Plagioclase slightly predominates over K-feldspar, clastogenic muscovite exceeds biotite. In places, biotite flakes are associated with chlorite. Zircon, tourmaline, rutile, glauconite, spinel and framboidal pyrite occur as accessory minerals. Lithic fragments are represented by limestones (sparitic and micritic), pelites, phyllites, mica schists, gneisses, granites, silicic rock fragments and volcanic glass.

In the Krynica Unit, clastic deposits of the flysch facies are represented by sublitharenites (sensu Pettijohn et al., 1972; Fig. 4A). They consist of quartz and feldspar with minor biotite, muscovite and accessories. Among quartz, monocrystalline quartz predominates over polycrystalline quartz $(\mathrm{Qm} / \mathrm{Qp}$ ratio varies in the interval from 3.7 to 8.14 ). Plagioclase exceeds potasium feldspar $(\mathrm{Plg} / \mathrm{Kfs}=1.7-3.5)$. Microcline and perthite are rare. Clastogenic chloritised and baueritised biotite usually dominates over muscovite. Resistant heavy minerals such as zircon, detrital and acicular tourmaline, garnet, rutile, glauconite and pyrite are also present in the arenites. Limestones, metamorphic rocks represented by mica schists, gneisses and phyllites, and sandstones, silicic rock fragments, granites, volcanics and basics are also present within this rock framework. Two types of binding material are encountered, which are calcite cement and matrix.

The sandstone-conglomerate facies contains sublitharenites and subarkoses (Fig. 4A; Pettijohn et al., 1972) with dominant monocrystalline quartz $(\mathrm{Qm} / \mathrm{Qp}=3.4-10.7)$. Plagioclase slightly exceeds potasium feldspar (Plg/Kfs $=1.3-1.9)$, only one sample showing an opposite trend $(\mathrm{Plg} / \mathrm{Kfs}=0.67)$. Clastogenic micas are represented by chloritised biotite and muscovite. Biotite prevails over muscovite, sporadically vice-versa. The accessory mineral assemblage comprises of detrital zircon, tourmaline, garnet, rutile, glauconite and framboidal pyrite. Lithic fragments are represented by limestones, sandstones, phyllites, mica schists, gneisses, granitoids, and volcanic and basic rocks. The binding material is formed by sparitic cement (somewhere up to $21 \%$ ) and matrix (usually up to $6 \%$ ), too.

Fine-grained sublitharenites with dominant monocrystalline quartz and abundand silicic rock fragments are typical for the menilite facies. Feldspar content is negligible. Clastogenic muscovite prevails over biotite, chlorite is scattered. Their acces-

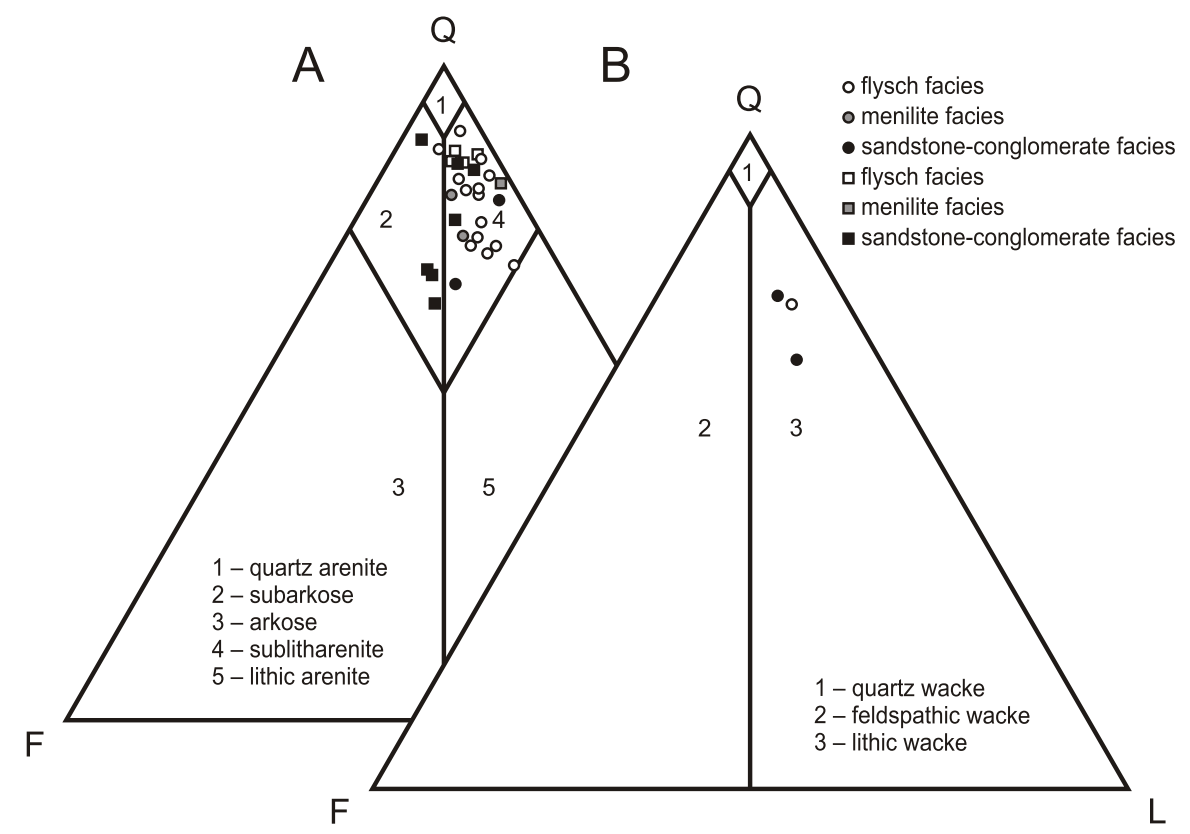

Fig. 4. Q-F-L classification of sandstones containing (A) less than $15 \%$ matrix and (B) more than $15 \%$ matrix after Pettijohn et al. (1972)

Circle - Inner Rača Unit, square - Krynica Unit, Q - monocrystalline and polycrystalline quartz, F - plagioclases and K-feldspars, L - lithic debris 
sory mineral assemblage consists of zircon, rutile, tourmaline, glauconite, spinel and framboidal pyrite. Lithic fragments show the same character as those ones in the Rača Unit.

Discrimination of sandstone provenance is according to the Dickinson's (1985) scheme and detrital modes were recalculated to $100 \%$ as the sum Qt, Qm, F, L and Lt. The Qt-F-L triangular plot emphasizes maturity, where as the Qm-Fm-Lt plot emphasizes primary deposition from source rocks. Dickinson's (1985) schemes suggest that the Malcov Fm. sediments were derived from a recycled orogen (Fig. 5A), mainly from a quartzose one (less transitional recycled orogen; Fig. 5B).

\section{HEAVY MINERALS}

Heavy mineral assemblages. The percentages of the heavy mineral assemblage components are given in Appendix 2. Garnet, rutile and zircon belong to the dominant group. Apart from these minerals, tourmaline, apatite, pyroxene, Cr-spinel, and traces of glauconite, staurolite, kyanite, amphibole, zoisite and chlorite were also found. Garnet dominates (up to 51 vol. \%) over zircon and rutile in both the Rača and Krynica units. The proportion of opaque minerals - pyrite and hematite (not given in Appendix 2), which are not important for provenance, significantly increases in the flysch facies (largely in the Rača Unit).

Heavy mineral geochemistry. The investigation of chemical composition and of the internal structure is focused on garnet, tourmaline, Cr-spinel and zircon, which are traditionally considered as moderately to highly stable detrital minerals indicative of provenance. The representative chemical compositions of detrital garnets, tourmalines and chromian spinels are shown in Appendix 3

Detrital garnet in the Malcov deposits often appears as slightly irregular-shaped fragments, sometimes with signs of corrosion on grain surfaces without retention of the original shape. Isometric grains occur occasionally, euhedral forms being rare (Fig. 6A). They are usually pink, sporadically colourless or or- ange. Inclusions of rutile, zircon, monazite, xenotime, quartz, apatite, calcite and ilmenite are commonly found in the garnets.

In the Rača Unit, from a compositional aspect, detrital garnets show a high variability. Grossular-almandine, pyropespessartine almandine, pyrope-almandine, almandine, spessartine-almandine and spessartine were recognized. Grossular-almandines are either (1) zonal, whereby the grossular (and partly spessartine) component $\left(\mathrm{And}_{1} \mathrm{Prp}_{5} \mathrm{Sps}_{8}\right.$ $\mathrm{Grs}_{31} \mathrm{Alm}_{55}$ ) slightly decreases towards grain peripheries with corresponding increase of the almandine molecule $\left(\mathrm{Adr}_{0} \mathrm{Sps}_{4}\right.$ $\operatorname{Prp}_{7} \mathrm{Grs}_{26} \mathrm{Alm}_{63}$ ), or (2) unzoned with a high almandine component $\left(\mathrm{Adr}_{0} \mathrm{Sps}_{1-4} \operatorname{Prp}_{4-8} \mathrm{Grs}_{13-17} \mathrm{Alm}_{75-77}\right)$. Another type of garnet is zonal pyrope-spessartine almandine $\left(\mathrm{Adr}_{0-2} \mathrm{Grs}_{2-12} \mathrm{Prp}_{9}\right.$ $\left.\mathrm{Sps}_{11-17} \mathrm{Alm}_{62-75}\right)$ with increase of grossular component towards the rim $\left(\mathrm{Adr}_{0} \mathrm{Prp}_{5-9} \mathrm{Sps}_{6-9} \mathrm{Grs}_{19-26} \mathrm{Alm}_{63}\right)$. Additional types of garnet are: unzoned pyrope-almandine with variable contents of the spessartine and grossular molecule ( $\mathrm{Adr}_{0} \mathrm{Grs}_{1-13}$ Sps $\left._{1-9} \operatorname{Prp}_{16-21} \mathrm{Alm}_{66-76}\right)$, almandine (Adr $\left.\mathrm{Grs}_{5} \mathrm{Sps}_{8} \mathrm{Prp}_{8} \mathrm{Alm}_{79}\right)$ and spessartine-almandine $\left(\mathrm{Adr}_{1} \mathrm{Grs}_{7} \operatorname{Prp}_{14} \mathrm{Sps}_{20} \mathrm{Alm} \mathrm{Im}_{58}\right)$. A zonal spessartine garnet was also found - the spessartine component in grain centre reaches $85.5 \mathrm{~mol} \%\left(\mathrm{Adr}_{1} \operatorname{Prp}_{1} \mathrm{Grs}_{6}\right.$ $\mathrm{Alm}_{7} \mathrm{Sps}_{86}$ ), while it rapidly drops at the rim at the expense of the almandine component (35.1 mol\% Sps; $A_{d r} \operatorname{Prp}_{3} \mathrm{Grs}_{14}$ $\mathrm{Sps}_{35} \mathrm{Alm}_{46}$ ).

In the Krynica Unit, the chemical composition of detrital garnets is likewise heterogeneous. There are (1) almost unzoned pyrope-spessartine-almandines $\quad\left(\mathrm{Adr}_{0} \mathrm{Grs}_{1-3} \operatorname{Prp}_{3-10} \mathrm{Sps}_{17-25}\right.$ Alm66-71), (2) garnets with increasing grossular (up to $27 \mathrm{~mol} \%$ ) and pyrope (up to $33 \mathrm{~mol} \%$ ) components at the expense of almandine (45-51 mol\%) (Adr $\mathrm{Sps}_{1} \mathrm{Prp}_{20-33} \mathrm{Grs}_{18-27} \mathrm{Alm}_{45-51}$; the high-temperature character of these garnets is indicated by a lack of zoning), (3) pyrope-almandine, in which grossular and spessartine contents are variable $\left(\mathrm{Adr}_{0} \mathrm{Sps}_{2-13} \mathrm{Grs}_{3-10}\right.$ $\left.\operatorname{Prp}_{13-16} \mathrm{Alm}_{69-72}\right)$, (4) grossular-almandine $\left(\mathrm{Adr}_{1} \mathrm{Sps}_{2} \mathrm{Prp}_{8} \mathrm{Grs}_{14}\right.$ Alm $\mathrm{m}_{75}$ ) and (5) zonal almandine-spessartine (54 mol\% Sps in the centre of the grain; $A_{d r} \operatorname{Prp}_{1} \mathrm{Grs}_{17} \mathrm{Alm}_{29} \mathrm{Sps}_{54}$ ), which is enriched in grossular and almandine components at the expense of spessartine in the rim $\left(\mathrm{Adr}_{0} \operatorname{Prp}_{3} \mathrm{Sps}_{12} \mathrm{Grs}_{22} \mathrm{Alm}_{63}\right)$.

\section{A}

1. Craton Interior

2. Transitional Continental

3. Basement Uplift

4. Recycled Orogen

5. Dissected Arc

6. Transitional Arc

7. Undissected Arc

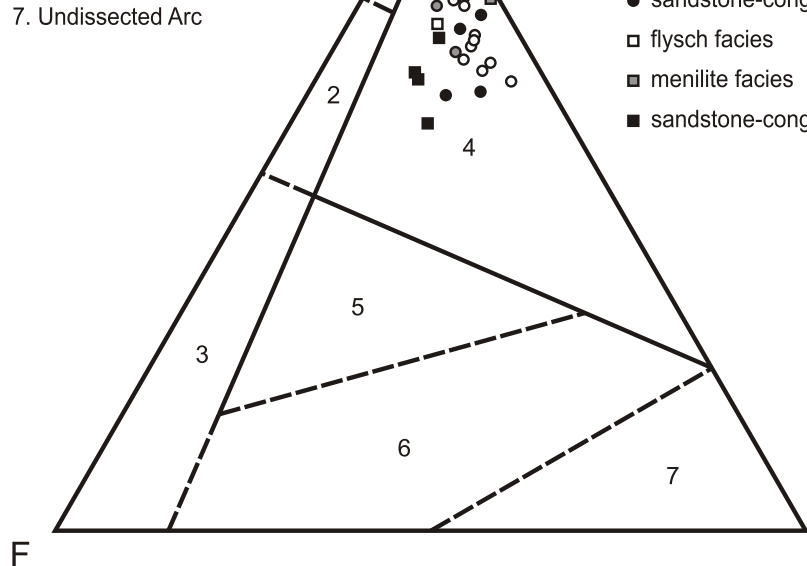

B

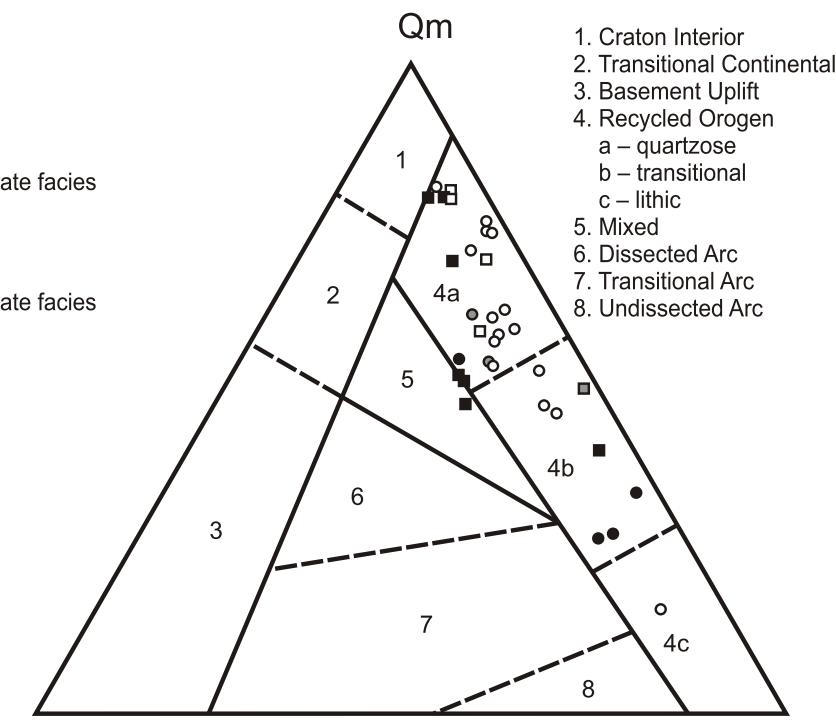

LF

Fig. 5. Qt-F-L (A) and Qm-F-Lt (B) tectonic discrimination diagrams of sandstone source areas after Dickinson (1985)

Qt - monocrystalline and polycrystalline quartz, Qm - monocrystalline quartz, Lt - lithic debris and polycrystalline quartz; other explanations as in Figure 4 

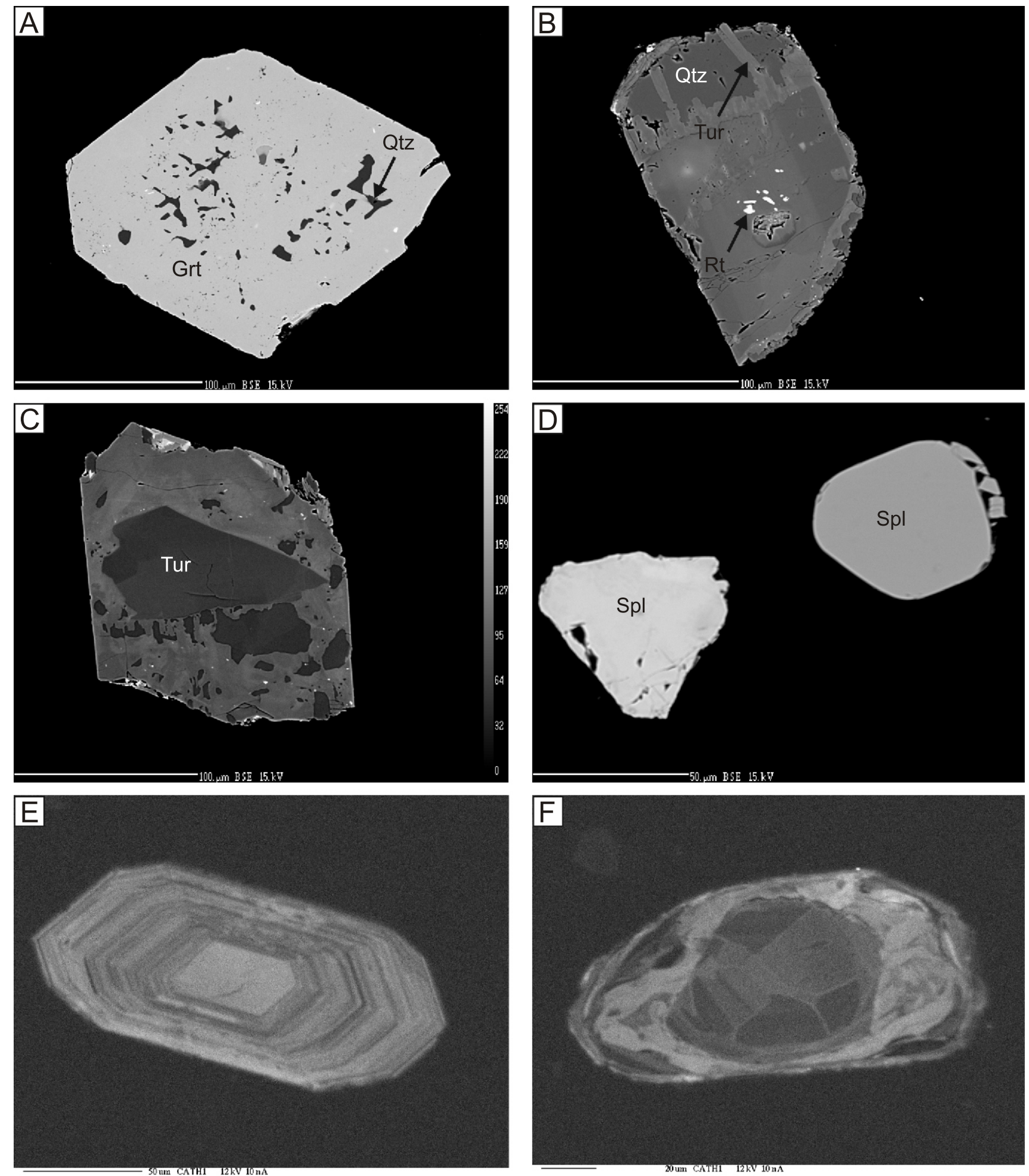

Fig. 6. Back-scattered electron (BSE) images of (A) garnet, $(B, C)$ tourmaline, (D) Cr-spinels and (E, F) cathodoluminescence (CL) images of zircons from deposits of the Malcov Fm. 
Detrital tourmaline occurs as short and abruptly terminated prismatic grains. Euhedral acicular grains appear rarely. Rounded and sub-rounded tourmalines are scarcer, usually of brown to dark brown colour. They are transparent to translucent with a glassy lustre. Some grains are inclusion-rich (Fig. 6B), with quartz, ilmenite and chlorite (Rača Unit). Zircon, rutile and quartz are enclosed in tourmalines from the Krynica Unit. For both units, tourmaline shows identical chemical composition.

Geochemistry of the tourmalines revealed that the dominant cation occupying the X-site position in all grains investigated chemically homogeneous and zoned - is $\mathrm{Na}$, which varies in the range of 0.5 to 0.9 a.p.f.u. Ca amount does not exceed of 0.2 a.p.f.u, while $\mathrm{K}$ content is in the range of 0.0 to 0.01 a.p.f.u. X-site vacancy is $<0.4$ a.p.f.u. Each of these may be classified as alkali tourmaline. Based on the dominant divalent cations in the $Y$-site position, which are $\mathrm{Fe}$ and $\mathrm{Mg}$, the tourmalines studied belong to dravitic tourmaline (Henry et al., 2011). Molar Fe/(Fe+Mg) values range from 0.22 to 0.49 . $\mathrm{Mg}$ and $\mathrm{Ca}$ contents in zonal tourmaline usually increase towards the grain peripheries but some zoning is reversed. In both cases, we assume a metamorphic origin of the tourmaline. $X$-vacancies vs. Ca ratio at the $X$ position indicate low- to medium-grade conditions of metamorphism (Henry and Dutrow, 1996).

Some tourmalines consist of a detrital core of schorlitic-dravitic composition $(\mathrm{Fe} /(\mathrm{Fe}+\mathrm{Mg})=0.58)$, surrounded by asymmetrical overgrowths with inner and outer rims, which mark abrupt chemical discontinuities. Nevertheless, these tourmalines retain a dravitic composition.

Rare inherited tourmaline cores with slightly rounded edges (Fig. 6C) display schorlitic compositions with rather high $\mathrm{Mn}$ contents $(0.14$ wt $\% \mathrm{MnO})$ and no $\mathrm{Cr}$, while rims of this zonal tourmaline show a dravitic compound. The molar $\mathrm{Fe} /(\mathrm{Fe}+\mathrm{Mg})$ ratio of the inherited core is 0.71 .

Unzoned tourmalines also show a dravitic composition.

Detrital chromian spinels are found as subhedral to euhedral grains (Fig. 6D), with rare fragments. According to Stevens's (1944) classification, which is based on Cr, Al and $\mathrm{Fe}^{3+}$ contents, the spinels are represented by aluminium-chromite and chromian-spinel. $\mathrm{Cr} \#$ and $\mathrm{Mg \#}$ parameters classify them as chromite, magnesiochromite and rarely spinel s.s. (Deer et al., 1992).

Spinels are usually unzoned and homogeneous. The chemical composition shows different contents of the main oxides: $\mathrm{Cr}_{2} \mathrm{O}_{3}$ (up to $50.50 \mathrm{wt}$ \%) which dominates in most of the grains analysed; $\mathrm{Al}_{2} \mathrm{O}_{3}$ content is within the range of 16.06 to 32.75 wt. $\%$, while the high $\mathrm{TiO}_{2}(0.70-2.30$ wt. \%) and the low $\left[\mathrm{Fe}^{2+} / \mathrm{Fe}^{3+}=(1.0-2.15)\right]$ ratio suggests a volcanic origin of the bulk of the grains analysed (Lenaz et al., 2000; Kamenetsky et al., 2001), with a Mg\# between 0.5 and 0.7 . Grains containing $\mathrm{TiO}_{2}$ up to 0.1 wt. $\%, \mathrm{Fe}^{2+} / \mathrm{Fe}^{3+}=(8.9-14.5)$ and $\mathrm{Mg \#}=$ $0.42-0.48$ are also present. Some grains are rich in $\mathrm{TiO}_{2}, \mathrm{Al}_{2} \mathrm{O}_{3}$ and $\mathrm{FeO}$, which increase at the expense of $\mathrm{Cr}_{2} \mathrm{O}_{3}$ towards the grain peripheries. Other grains show higher contents of $\mathrm{MnO}$ (0.49 wt. \%) and $\mathrm{ZnO}(0.43 \mathrm{wt} . \%)$, which may indicate alteration processes, although these are not shown by grain textures. Also, Zhu et al. (2004) considered the content of $\mathrm{MnO}$ $<0.5$ wt. \% as typical of spinels. $\mathrm{A}$ decrease in $\mathrm{Al}_{2} \mathrm{O}_{3}$ content at the peripheries of grains, typical of alteration and/or metamorphic processes, does not occur.

According to the diagram used to determine Cr-spinel origin (Lenaz et al., 2000; Kamenetsky et al., 2001), the samples investigated lie in the field of suprasubduction zone peridotites and volcanic spinels, respectively. The volcanic spinels fall outside the boundaries of different tectonic settings (Fig. 7C).

Zircon internal structure. Zircon forms either euhedral to subhedral short-prismatic dipyramidal grains or long-prismatic ones without signs of corrosion and cutting of edges. Both groups are colourless or pink. Rounded zircon shapes are also present. Their colour is the same - colourless, pink, rarely yellowish.

According to cathodoluminescence study, euhedral to subhedral short-prismatic zircons usually precipitate from nuclei or around inherited cores (Fig. 6E) and display a regular oscillatory zoning without marginal resorption. In some grains, local recrystallisation is observed. This may be associated with a late- to post-magmatic stage of zircon development. The presence of inclusions, such as apatite and melt, is common. The internal structure of the long-prismatic zircon also shows regular oscillatory zoning.

Rounded zircons indicate a polycyclic history. The occurrence of inherited cores is a common feature of many rounded zircons. For some zircons an irregular zoning is typical. Additional zircon grains are characterized by convolute zoning due to recrystallisation processes (Fig. 6F). Zircons have been found with inherited cores showing no zoning, on which a narrow zone with regular oscillatory zoning is present.

Dendritic grains shifting to polyhedral morphology with parallel zoning to the crystallographic $\mathrm{c}$ axis showing rapid growth of the zircon are also present.

\section{DISCUSSION}

\section{SEDIMENTOLOGY AND PALAEOFLOW TRANSPORT}

We infer that the Malcov Formation (together with the uppermost, Oligocene part of the Zlín Fm. in the Rača Unit) originated in several small-sized sub-basins the axes of which run NW-SE. Formation and isolation of these sub-basins are associated with Alpine tectonics and transformation of the remnant Outer Western Carpathians basin into a flexed foreland basin (e.g., Oszczypko, 2006). The sub-basins have characteristics of piggy-back basins (sensu Ori and Friend, 1984) developed on the top of the frontal part of the Western Carpathians orogenic wedge, which constitutes a wedge-top depozone (sensu DeCelles and Giles, 1996) of the foreland basin. The nature of the processes and sediments in the sub-basins was also affected by climate change at the boundary between the Eocene and Oligocene (Terminal Eocene Event) when significant cooling of the climate and glacio-eustatic regression started (e.g., Leszczyński, 1997; Soták, 2010; OszczypkoClowes and Zydek, 2012). From the Early Oligocene the Carpathian basins provided the first records of isolation from the open sea (Early Paratethys; Báldi, 1980, 1984). The palaeoenvironmental changes reflected the cooling of the climate and isolation of the Paratethys. The consequences of these changes are the Globigerina Marls, menilite facies and laminated limestones that commenced at the boundary between the Eocene and Oligocene (nannoplankton zone NP21). The shape and size of the sub-basins significantly affected the sedimentation of the clastic deposits.

Marginal parts of the Malcov sub-basins [in our case two sub-basins have been distinguished - the southern (inner) sub-basin in the Krynica Unit and the northern (outer) sub-basin in the Inner Rača Unit] were deformed and older successions of surrounding units of the Magura Nappe and Klippen Belt were uplifted. The deformation of the successions therefore occurred before and during sedimentation, and immediately afterwards, respectively (e.g., Świerczewska and Tokarski, 1998) and continued to the Early Miocene. We assume that the southern edge of the southern sub-basin was formed from uplifted units of the 
A

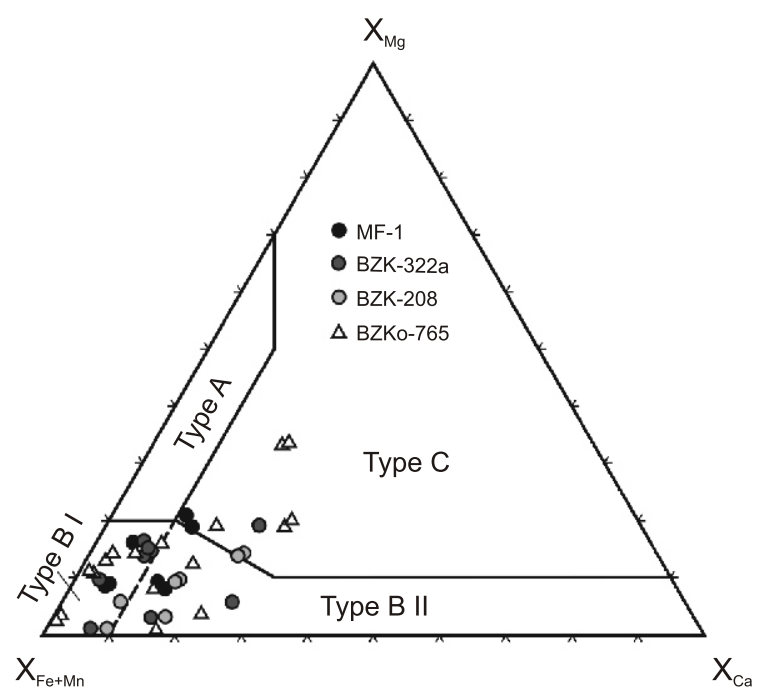

B

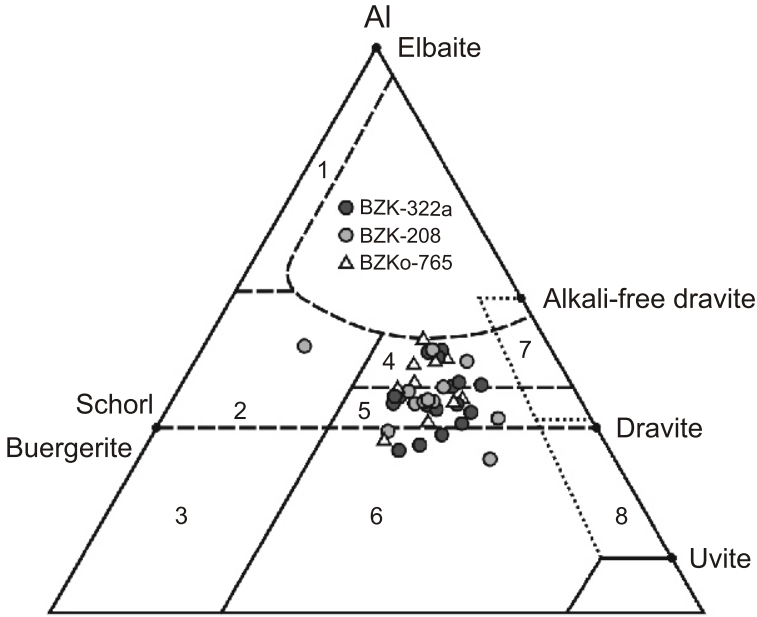

C

$\mathrm{Al}_{50} \mathrm{Fe}(\text { tot })_{50}$

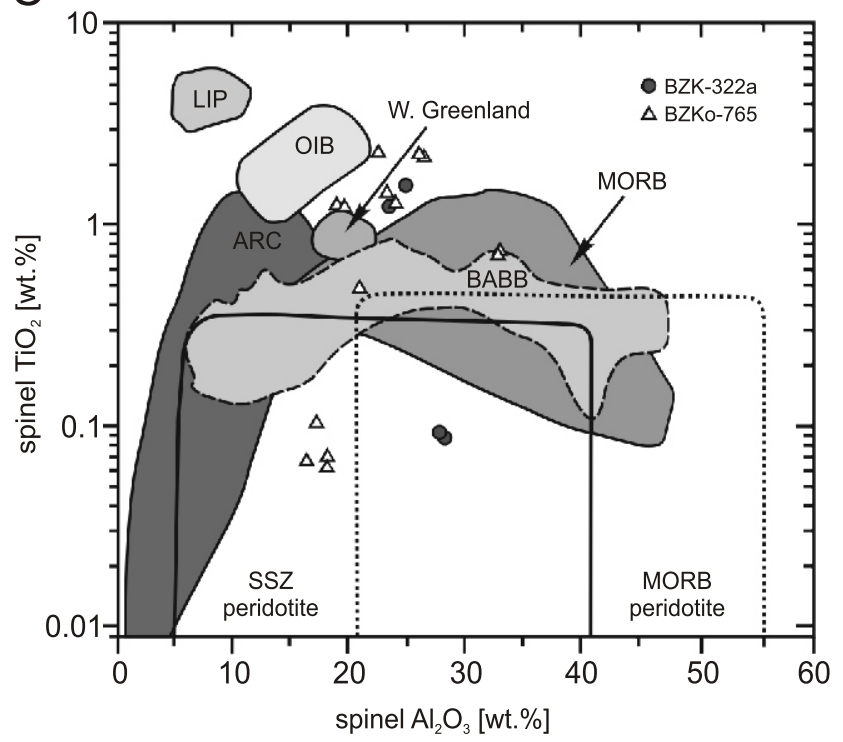

PKB and the Magura Nappe (the Proč, Čergov and Strihovce fms.), whereas the northern edge of the sub-basin was formed from deformed strata of the Bystrica Unit sedimentation area. The structural elevation of the uplifted Bystrica Unit (the sedimentation area of this unit) was also the southern boundary of the northern sub-basin. The northern sub-basin was bounded by a slightly uplifted external part of forming Rača Unit on the northern side. We understand the individual structural elevations as submerged ridges parallel to the direction of the Magura Basin (NW-SE in recent coordinates of the study region). Older (Late Cretaceous to Eocene) flysch sediments may have been redeposited from these ridges via submarine slumps and various types of gravity currents to neighbouring Malcov sub-basins in a transverse direction (NE-SW). Deposition of the Malcov Fm. lithofacies in relatively small sub-basins is also indicated by the palaeoflow record. Variable palaeoflow data highlights the contribution of sedimentary material from several directions and/or diversion of gravity currents from the main flow direction. Besides the dominant flow direction from SE to NW [longitudinal transverse input of clastic sediments from peripheral parts (structural elevations)] of sub-basins also had a significant impact on final clastic composition.

Palaeoflow analysis shows that the main clastic source area was situated to SE of the Malcov sub-basins. We propose the Marmarosh Massif as the main clastic source, despite some considerations about its NE position (Oszczypko, 2004; Oszczypko et al., 2005b, 2015) or its position between the Dukla and Magura basins (Oszczypko and Oszczypko-Clowes, 2009; Gągała et al., 2012), respectively. The presence of the intra-basinal Marmarosh Ridge between the Magura and Dukla basins was suggested by Leszczyński and Malata (2002); Ślączka et al. (2006), Warchoł (2007) and Gągała et al. (2012). It uplifted along the forebulge during the Late Eocene and drowned in Early Oligocene due to tectonic loading (Gągała et al., 2012). On the other hand, Koráb and Ďurkovič $(1973,1978)$ demonstrated the existence of a single sedimentary basin for the Magura and Dukla units during the Middle Cretaceous to Early Oligocene in Eastern Slovakia, i.e. these units were sedimented in a basin which was not divided by a ridge.

\section{HEAVY MINERALS AND THEIR POSSIBLE ORIGIN}

The ZTR index (percentage of the combined zircon, tourmaline and rutile grains among the transparent, nonmicaceous, detrital heavy minerals sensu Hubert, 1962), which reflects sediment maturity, is within the range of $47-56 \%$ for the Rača Unit, and of $36-50 \%$ for the Krynica Unit. The ZTR index suggests

Fig. 7A - composition of detrital garnets from the Malcov Fm. in a $\mathrm{Fe}+\mathrm{Mn}-\mathrm{Mg}$-Ca ternary diagram (Morton et al., 2004); B Al-Fe-Mg diagram for tourmalines (Henry and Guidotti, 1985); C - composition of analysed $\mathrm{Cr}$-spinels in a $\mathrm{Al}_{2} \mathrm{O}_{3}$ vs. $\mathrm{TiO}_{2}$ diagram (Kamenetsky et al., 2001)

Type A - Grt from granulites, type BI - Grt from intermediate to acid igneous rocks, type B II - Grt from metasedimentary rocks of amphibolite facies, type C - Grt from metabasic rocks; 1 - Li-rich granites, 2 - Li-poor granites and aplites, 3, $6-\mathrm{Fe}^{3+}$-rich quartz-tourmaline rocks, 4 - metapelites and metapsammites co-existing with Al-rich phases, 5 - metapelites and metapsammites not co-existing with Al-rich phases, 7 - low-Ca metaultramafic rocks, $\mathrm{Cr}$ - and V- rich metasedimentary rocks, 8 - metacarbonates and metapyroxenites; LIP - large igneous provinces, OIB - ocean-island basalt, MORB mid-ocean ridge basalt, ARC - island-arc basalt, SSZ - peridotite of supra-subduction zone, BABB - back-arc basin basalt (after Lenaz et al., 2000) 
the erosion of crystalline massifs, excluding multi-cycle sediments, for which ZTR $>90 \%$ is typical (Hubert, 1962). A medium value of the ZTR index indicates a relatively close source, and insignificant role of intrastratal dissolution, which is influenced by burial depth (Morton, 1987).

The garnet/zircon index (GZi; Morton and Hallsworth, 1994), the value of which could be affected by diagenetic processes and intrastratal dissolution of garnet, varies from 65 to $74 \%$ for the Krynica Unit and from 60 to $66 \%$ for the Rača Unit. The chromian-spinel/zircon index (CZi; Morton and Hallsworth, 1994), the value of which varies from 6 to $9 \%$ and from 17 to $24 \%$ for the Rača and Krynica units, respectively, provides a good reflection of source area characteristics because these minerals are comparatively immune to alteration during the sedimentary cycle. This index could be used to directly match sediment with the source material, even for suites of first-cycle origin (Morton and Hallsworth, 1994). Its higher value indicates that an important proportion of ophiolite detritus was supplied chiefly for the Krynica Unit.

Index minerals such as staurolite, kyanite and sillimanite are valid only for certain settings, i.e. Barrovian-type metamorphism of Al-rich pelitic rocks. The presence of these rocks in the source area is evident from tourmaline and garnet geochemistry and pebbles such as clasts of gneiss and mica schist. The existence of staurolite in sandstone-conglomerate facies of the Malcov Fm. (Rača Unit) is confirmed, while kyanite is rare (Appendix 2). Ďurkovič (1965) described a "relatively low content of staurolite in Malcov layers" within the Rača Unit. It is relatively abundant in the subjacent Beloveža Fm. (Fejdiová, 1990). Kyanite is present in the flysch facies of the Krynica Unit, while staurolite is uncommon. Despite the conclusions resulting from the study of the transformation of smectite to illite (Świerczewska, 2005) or from the study of fluid inclusions in hydrothermal quartz, which involve the loss of 5.4-7.4 km of sediment by erosion in the Magura Basin (Hurai et al., 2006), a decrease in staurolite and kyanite concentration or their dissolution influenced by sediment burial is not assumed, because less stable minerals such as pyroxenes and amphiboles (Appendix 2) are retained in the heavy mineral spectra. As regards intrastratal dissolution, these minerals are extremly susceptible due to sediment burial depths besides other factors affecting dissolution (Scavnicar, 1979; Morton, 1984; Morton and Hallsworth, 1999, 2007). The transformation of smectite to illite which is directly dependent on fluid circulation, excludes a low permeability which could protect the sediment from circulation of pore fluids thus to prevent the disintegration of unstable heavy minerals. The presence of amphibole suggests that significant post-depositional dissolution is unlikely to have taken place. Pyroxenes and rare amphiboles are also present in the subjacent formations (Fejdiová, 1990). The existence of Ca-rich garnets, which are less stable than Ca-poor ones during diagenesis (Morton and Hallsworth, 2007), was also noticed. In general, dissolution of garnet is not supported because of the high GZi value (Morton and Hallsworth, 1994, 1999). A decrease of mineral diversity with increasing burial depth is also not obvious (cf. Fejdiová, 1990). Etched garnet co-exists with garnet grains that show no sign of corrosion, indicating that the etching did not take place in situ.

Apart from the occurrence of specific minerals, single grain characteristics are used to deduce the metamorphic origin of detrital grains and to further unravel the type of metamorphic host-rocks. The compositional variation of garnet is large, making it a candidate for source rock discrimination based on single-grain geochemistry.

Chemical composition of detrital garnets, and also the distribution of inclusions in these grains suggest that most of them were derived from metamorphic rocks that originated within conditions of amphibolite or even epidote-amphibolite facies. Their metamorphic origin is likewise demonstrated by the high garnet/zircon index (GZi), which sensitively reflects provenance characteristics of heavy minerals in sediments (Morton and Hallsworth, 1994, 1999).

Garnets with significant $\mathrm{Fe}$ and Mn contents may be derived from low- to medium-grade metasediments or from intermediate to acidic gneisses (Deer et al., 1992; Morton et al., 2004; Suggate and Hall, 2013). Garnets from low-grade metapelites are characterized by zoning, and a zoned pattern of some detrital garnets is visible (Appendix 3 ). Zoned grossular-almandines obviously originated from source rocks of low-grade amphibolite facies. The presence of low- to medium-grade metamorphic rocks (phyllites, mica schists) in the source area is supported by their existence in the form of lithic fragments in the deposits studied. Spessartine-almandine garnets, in which chemical zoning is scarcer, though pyrope (around 10-12 mol\%) and grossular (around $15 \mathrm{~mol} \%$ ) molecules are relatively abundant, might have originated in migmatites (?) or gneisses. Spessartine-almandines (with $1-3 \mathrm{~mol} \% \mathrm{Grs}$ ) showing the least chemical changes in the core - periphery direction point to a genesis in granitic pegmatites or granites. They occur in deposits of both the Rača and Krynica units. According to Mange and Morton's (2007) criteria, low Ca and Mg contents in garnet indicate their provenance in intermediate to acidic igneous rocks (Fig. 7A). Garnets with significant grossular molecule (up to $27 \mathrm{~mol} \%$ ) and a slightly higher content of pyrope (up to $33 \mathrm{~mol} \%$ ), which increases at the expense of almandine (45-62 mol\%) component, indicate their derivation from basic metamorphic rocks (amphibolites or mafic granulites).

Spessartine-rich garnet appears as a distinct indicator of its background. Spessartines with low amounts of grossular content are known to originate from low-grade regionally metamorphosed rocks such as metapelites, metacherts, especially those in thermal aureoles (Miyashiro, 1955; Deer et al., 1982; Spišiak et al., 1989; Méres, 2008), or from Mn carbonate-silicate rocks (Matkovskyi, 1971; Deer et al., 1992; Mohapatra and Nayak, 2005; Matkovskyi et al., 2011; Kanungo et al., 2014), moreover, from garnetites (often with high andradite component, Kropáč, 2012) and gondites (Melcher, 1995; Matkovskyi et al., 2011; Vrána, 2011). They have rarely been found in granite pegmatites (Manning, 1983; Baldwin and Von Knorring, 1983; Királi and Török, 2003), and in blueschists, with an absence of zoning (Martínek and Štolfová, 2009). Normal zoning of spessartines denotes their formation under conditions of progressive metamorphism. Ca enrichment, coupled with depletion of $\mathrm{Mn}$ at the rims of the garnets, may have been caused by pressure increase (Green, 1977) or by recrystallisation through the medium of Ca-rich fluids (Királi and Török, 2003).

Generally, there are minimal differences in the chemical composition between detrital garnets from the Rača and Krynica units, respectively. However, the source rocks are heterogeneous. Certain proportion of garnets in the Malcov deposits could have resulted from resedimentation from the older formations of the Magura Nappe.

Tourmaline is primarily derived from metamorphic, mostly metapelitic rocks. Detrital tourmalines, according to the diagram from Henry and Guidotti (1985; Fig. 7B), which is used for determination of environment for tourmaline origin, were derived from Al-poor and Al-rich metasedimentary rocks. Their metamorphic origin is also indicated by relatively high $\mathrm{Ti}$ (up to 0.3 a.p.f.u.) contents.

The tourmaline investigated represents mainly polycyclic grains - they are either (1) zoned with inherited schorlitic-dravitic cores derived from metapelite (metapsammite) co-existing with 
Al-saturated phases and with rims derived from Al-saturated phases-free metapelite (Henry and Guidotti, 1985); or (2) zoned tourmalines with inherited schorlitic cores derived from granite (granite differentiates). The inner margins of zoned tourmalines from the second group indicates their origin in Al-saturated phase-free metapelites, while their outer rim was formed in an Al-rich metapelite environment. The presence of the inner and outer rims separated by compositional discontinuities around some inherited cores suggests punctuated evolution of the overgrowths. This implies that boron was sporadically available during diagenesis and metamorphism (Henry and Dutrow, 1992).

Tourmalines originated from $\mathrm{Fe}^{3+}$-rich quartz-tourmaline rocks bordered by zones formed in a metapelite environment.

The scarce euhedral acicular tourmalines were derived from metapelites with Al-saturated phases, most probably representing first-cycle delivery from a nearby source. The very low contents (often zero value) of tetrahedral $\mathrm{Al}$ and the $X_{\text {vac }}$ values around $0.2-0.3$ a.p.f.u. suggest medium-grade metamorphic conditions during their precipitation (Henry and Dutrow, 1996).

Most studies have reported a strong predominance of tourmaline from metasedimentary rocks, although tourmaline is very common in granitoids and their differentiates (von Eynatten and Gaupp, 1999; Morton et al., 2005; von Eynatten and Dunkl, 2012). This might be caused by (1) inherited grain size effects and/or (2) the possibly higher stability of Mg-rich tourmaline against extreme weathering (Van Loon and Mange, 2007; von Eynatten and Dunkl, 2012). More importantly, there might be a direct relationship between grain size and composition, i.e. specific mineral phases may show systematically contrasting grain-size distributions in the same or different source rocks (von Eynatten and Dunkl, 2012). Ultimately, the grain size distribution in the source rocks controls the availability of specific mineral grain sizes in the sediment (Morton and Hallsworth, 1999). These possibilities may have caused the dravitic tourmaline dominance in the Malcov Fm. deposits.

Detrital zircons exhibit variations not only in external morphology but also in internal textures. Euhedral zircons originate from primary igneous rocks. Zircons crystallising from nuclei showing fine regular oscillatory zoning, often without signs of resorption, may have formed in "early" melts (Hoskin and Schaltegger, 2003). Zircon elongation is considered as a factor reflecting grain crystallisation velocity (e.g., Corfu et al., 2003). "Stubby" and equant forms are associated with slowly cooled intrusions, whereas elongate acicular shapes occur as a result of rapid crystallization and are traditionally interpreted as of volcanic origin (Hoskin and Schaltegger, 2003). Complete euhedral shapes of zircons indicate their igneous origin without prolonged transport from the source region. The presence of inclusions, such as of apatite and melt, supports the igneous origin of this zircon group.

The origin of rounded grains in metasedimentary rocks, possibly in older recycled sediments, is documented not only by the zircon shapes, but also by their internal textures (Fig. 6F). The polymict character of the zircons indicates multiple source rocks.

Chromian spinels in the heavy mineral spectra signal some contribution of mafic to ultramafic rocks. The lithic fragments originated in these rocks are preserved in small amounts due to their easy disintegration during transport or diagenesis (BZKo-765, BZG-407 samples). Starobová (1962), Winkler and Ślączka (1992, 1994) and Oszczypko and Salata (2005) noted the significant amount of $\mathrm{Cr}$-spinels in deposits from the southernmost areas of the Magura Basin. Consideration of reworked or re-eroded sediments from the Pieniny Klippen Belt (sensu lato) or more precisely from the Czorsztyn ridge realm (Winkler and Ślączka, 1994), as a possible source of Cr-spinels occurring in the Magura Basin deposits, cannot be excluded completely.
According to Lenaz et al. (2000), we discriminate between peridotitic and volcanic $\mathrm{Cr}$-spinels on the basis of their $\mathrm{TiO}_{2}$ contents and $\mathrm{FeO} / \mathrm{Fe}_{2} \mathrm{O}_{3}$ ratios. Lenaz et al. (2000) pointed out that peridotitic spinels show $\mathrm{TiO}_{2}$ contents $<0.2$ wt.\% and $\mathrm{FeO} / \mathrm{Fe}_{2} \mathrm{O}_{3}$ ratios $>3$, while spinels crystallised from basaltic magmas show $\mathrm{TiO}_{2}$ contents $>0.2$ wt. $\%$ and $\mathrm{FeO} / \mathrm{Fe}_{2} \mathrm{O}_{3}$ ratios $<4$. Cr-spinels originating from cumulate and extrusive volcanic rocks tend to have higher $\mathrm{TiO}_{2}$ (Kamenetsky et al., 2001).

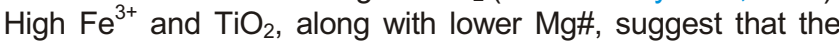
Cr-spinels could have been the products of fractional crystallisation and re-equilibration at lower temperatures due to slow cooling (Arai, 1992; Kamenetsky et al., 2001; Lužar-Oberiter et al., 2009), and thus probably derived from cumulate members of an ophiolite source. The increased contents of $\mathrm{TiO}_{2}$ in most $\mathrm{Cr}$-spinels from the Malcov Fm. are noticeable. Compared to Cr-spinels from the Czorsztyn Unit (Aubrecht et al., 2008, 2009), perhaps even the Jarmuta Fm. (PKB) and the Szczawnica Fm. (Magura Nappe, Krynica Unit, Salata, 2002a), there are some differences: Cr-spinels originated from volcanic rocks are predominant in the Malcov Fm., nevertheless peridotite spinels dominate in the Czorsztyn flysch. Increased amounts of oxides could have been caused by alteration. However, the majority of the grains analysed have optically and chemically homogeneous compositions (Fig. 6D). Significant decreases in $\mathrm{Al}_{2} \mathrm{O}_{3}, \mathrm{MgO}$ and $\mathrm{Cr}_{2} \mathrm{O}_{3}$, which might result from the alteration of Cr-spinels (Burkhard, 1993; Power et al., 2000, Spišiak et al., 2000, 2001; Mikuš et al., 2006; Mikuš and Spišiak, 2007), has not been observed.

Power et al. (2000) imputed the high Ti content in spinels to the solidus-solidus reactions between spinel and plagioclase in ophiolites. Spišiak et al. (2001) considered the Cr-spinels from the Šambron flysch zone (Central-Carpathian Paleogene Ba$\sin$ ) to have been derived from two sources at least, although they included the possibility of resedimentation. According to Spišiak et al. (2001), the Cr-spinels investigated resemble the Cr-spinels derived from ultrabasic rocks from the Zbudza locality (Iňačovce-Krichevo Unit; Soták et al., 1990, 1991, 1995), or from ultrabasic rocks cropping out in Gemericum, as well as the spinels from the PKB, or Magura flysch units of the Polish Western Carpathians. However, low $\mathrm{Ti}$ contents in these $\mathrm{Cr}$-spinels are notable (cf. Spišiak et al., 2001). The heterogeneous character of Cr-spinels in the Šambron Zone sediments was also shown by Lenaz et al. (2001, 2009), who described the similarity with spinels from the Vardar Zone. Peridotite spinels are prevalent (representing $90 \%$ of the spinels investigated, derived from peridotite of type II sensu Dick and Bullen, 1984). Scattered volcanic spinels have OIB character (Lenaz et al., 2009). Cr-spinels coupled with leucoxene are dominant in heavy mineral spectra, while garnets are entirely absent (Spišiak et al., 2001). Serpentinite clasts predominate in sandstones of the Sambron flysch zone, so it shows the clear dominance of basic sources in the Paleogene (especially the Late Oligocene; Soták and Bebej, 1996). These are deposits of perisuture basins, which were originally connected with trench-like flysch deposits of the Magura Unit (Soták and Bebej, 1996). Preliminary geochemical data of Cr-spinels from the Magura Formation of the Polish Western Carpathians indicate their affinity to the Vardar Zone (Lenaz et al., 2001).

The association of heavy minerals, their geochemical composition and petrographic analysis point to a heterogeneous source for the Malcov sediments. There is a combination of material, in particular of supra-crustal origin derived from metasediments recrystallised at the conditions of amphibolite and green-schist facies, partly from older strata, granitoid rocks and carbonates.

The petrographic study of the Malcov deposits revealed the predominance of monocrystalline quartz over polycrystalline 
quartz. This indicates that the sediments may have been partialy derived from a granitic source (Basu et al., 1975). The influence of igneous rocks on the sandstone composition is documented (1) by the presence of feldspars (K-feldspars), (2) by granite (and volcanic) fragments in the deposits and (3) by the existence of magmatic zircon in the heavy mineral spectra.

Dickinson's (1985) schemes suggest that the Malcov sediments were derived from recycled orogens shedding material of continental affinity into the basin. Evidence for partial recycling is apparent from bulk sediment composition (high percentages of quartz) indicating upward petrographical maturity ( $Q m>Q p)$, as well as from a zircon and chromian spinel enrichment due to their high stability within the sedimentary cycle. Heavy mineral ratios (CZi and GZi; Morton and Hallsworth, 1994) reflect minimal alteration of the Malcov deposits and/or invariant transport. The medium to high ZTR value, coupled with the heterogeneous character of the heavy mineral spectra, may point to a mixed source which is characterized by first-cycle detritus (e.g. acicular tourmaline) from a metamorphic basement representing remnants of continental margins, as well as by polycyclic detritus recycled from orogeny-derived clastic wedges (Garzanti et al., 2007).

\section{PALAEOGEOGRAPHIC IMPLICATIONS}

Minerals from rocks of supra-crustal origin dominate in the heavy mineral associations analysed. Some involvement of basic sources is indicated by $\mathrm{Cr}$-spinel occurrence. Considering their character and occurence within subjacent formations, their redeposition may be inferred.

We do not consider the lňačovce-Krichevo Unit as a possible (original) source of basic material, since its outcrop and exhumation are datable to the Lower Miocene based on the FT zircon age (Soták et al., 2000, 2005). Additionally, Malcov detrital Cr-spinels show some geochemical differences compared with the spinels from this unit (Zbudza locality).

Cr-spinels may have been derived from the Pieniny Klippen Belt (PKB). However, we note the predominance of volcanic $\mathrm{Cr}$-spinels in the Malcov deposits which are in a minority in the Czorsztyn Unit (Aubrecht et al., 2008, 2009) or the Jarmuta Fm. (Salata, 2002a). Sporadic volcanic Cr-spinel compositions appear to be more heterogeneous and change from ARC to MORB in the PKB (Lenaz et al., 2009). Cr-spinels from the Malcov Fm. show some compositional similarity (volcanic origin) with those from the Poruba Fm. (cf. Mikuš et al., 2006). Mikuš et al. (2006) inferred an affinity to the Meliata Ocean. Aubrecht et al. (2009) proposed the same origin for Cr-spinels from the Czorsztyn Unit considering as a source the exotic Andrusov Ridge, representing the Meliata melange supplying the Central-Carpathian Zone in the south, and Oravicum (PKB) in the north by ophiolite detritus simultaneously.

Communication between the Magura and Central-Carpathian Paleogene basins (CCPB; Leško, 1960 Nemčok, 1961; Leško and Samuel, 1968; Birkenmajer, 1986; Soták and Bebej, 1996; Oszczypko et al., 2005a, 2010; Jurewicz, 2005; Oszczypko and Oszczypko-Clowes, 2009; Soták, 2010; Oszczypko-Clowes and Zydek, 2012) during the Late Eocene to Oligocene may be considered. Malcov flysch sediments developed in the PKB depressions (Nemčok, 1961,1990; Oszczypko et al., 2005a; Plašienka and Mikuš, 2010; Plašienka, 2011), and in depressions between the PKB and the Šambron-Kamenica Zone of the CCPB (Plašienka and Mikuš, 2010), also point to this. Nevertheless, we do not suggest their total interconnection (Jurewicz, 2005).
Following the analyses of palaeocurrents and petrography, heavy mineral spectra and geochemical composition of the detrital minerals, we consider the Marmarosh Massif as the most possible source of material for the Malcov deposits, especially in the Rača Unit (Fig. 8). This provenance [Marmarosh Ridge (Cordillera)/Marmarosh (Rakhov) Massif] was proposed by Leško and Samuel (1968), Potfaj (1998), Oszczypko (2004), Oszczypko et al. (2005b), Oszczypko and Oszczypko-Clowes (2006) for Magura sediments in different intervals of the Paleogene. The rocks of the Marmarosh crystalline basement (currently cropping out along the Ukrainian-Romanian border) are composed of metamorphic rocks of green-schist facies,

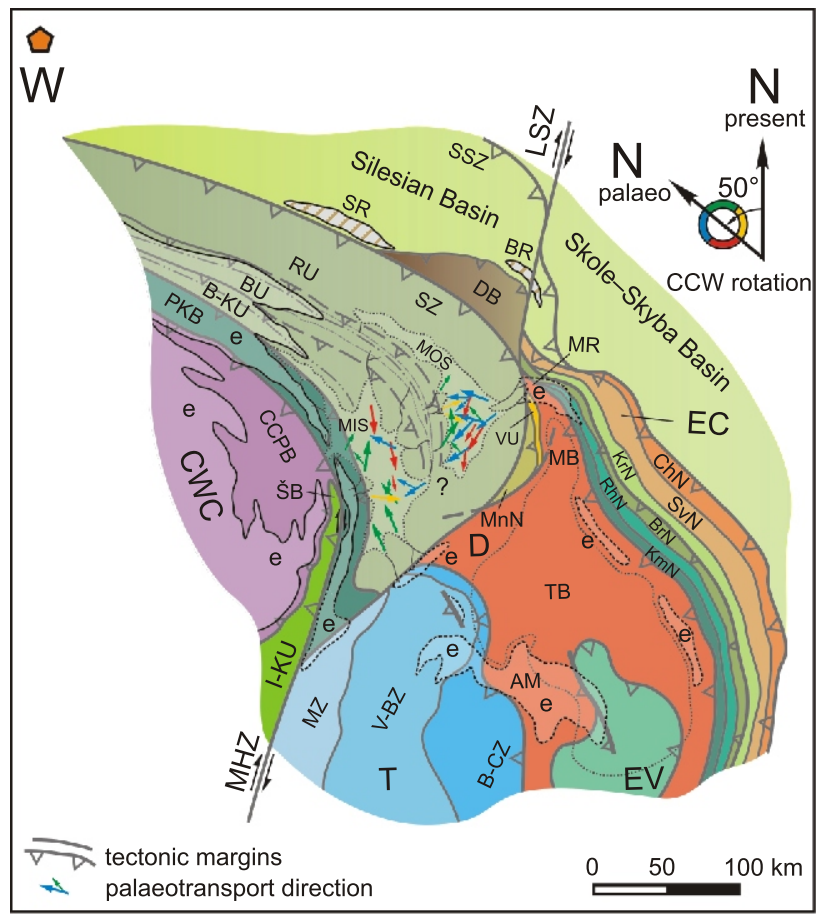

Fig. 8. Schematic palaeogeographic situation of the Magura Basin and adjacent tectonic units during the initial Late Oligocene (based on Koráb et al., 1962; Stránik, 1965; Contescu et al., 1966; Nemčok and Duurkovič, 1989; Kováč et al., 1994; Leszczyński, 1997; Csontos and Vörös, 2004; Ślączka, 2005; Oszczypko and Oszczypko-Clowes, 2006, 2009; Márton et al. 2007, 2013; Schmid et al., 2008; Ustaszewski et al., 2008; Merten, 2011; Merten et al., 2011; Handy et al., 2014; Hnylko and Generalova, 2014; Plašienka and Soták, 2015; Hnylko et al., 2015a, b; Hnylko and Hnylko, 2016)

Magura Basin: SZ - Siary Zone, RU - Rača Unit (zone), BU Bystrica Unit (zone), B-KU - Biele Karpaty-Krynica Unit (zone); MnN - Monastyrets Nappe; DB - Dukla Basin, SR - Silesian Ridge (Cordillera); BR - Bukowiec Ridge (Cordillera); CWC - Central Western Carpathians; PKB - Pieniny Klippen Belt; CCPB - Central-Carpathian Paleogene Basin; ŠB - Šambron Basin; I-KU Iňačovce-Krichevo Unit; Tisza Mega-Unit $(T)$ : $M Z$ - Mecsek Zone, V-BZ - Villány-Bihor Zone, B-CZ - Békés-Codru Zone; Dacia Mega-Unit (D): TB - Transylvanian Basin (land and epicontinental area), MB - Maramures Basin (trough), AM - Apuseni Mts.; VU Vezhany Unit; EV - Eastern Vardar ophiolitic unit; Eastern Carpathians (EC): MR - Marmarosh (Rakhov) Ridge, Fore-Marmarosh Suture (Ceahlau): KmN - Kamyanyi Potik Nappe, $\mathrm{RhN}$ - Rakhiv Nappe, BrN - Burkut Nappe; KrN - Krasnoshora Nappe, SvN - Svydovets Nappe, ChN - Chornohora Nappe; MHZ Mid-Hungarian Zone; LSZ - Latorytsa-Stryi strike-slip Zone; W Wien, e-emergent areas 
epidote-amphibolite and amphibolite facies (mica schists with garnet, sporadically with staurolite, gneisses, quartzites, amphibolites and amphibolite gneisses, schists) and granites (Săndulescu and Bercia, 1974; Zlatogurskaya et al., 1976; Rastochinskaya et al., 1981; Burov et al., 1986). The presence of rocks with lenses of rodonite-rodochrozite mineralisation (with spessartine) in Paleozoic complexes is also observed (Zlatogurskaya et al., 1976; Matkovskyi et al., 2011), and the zoned spessartine garnet ( $\sim 85 \mathrm{~mol} \% \mathrm{Sps})$ could have originated from it. Spessartines with subordinate content of grs and alm components are described in garnet-magnetite-quartzite, garnet-quartzite rocks (gondites) and calcareous-siliceous manganese ores within the northern part of the Marmarosh Massif (Chivchiny Mountains; Matkovskyi, 1971; Matkovskyi et al., 2011). Spessartines are also known from the Marmarosh Massif attached to the Romanian Carpathians (Preluca Massif), usually with a higher molar content of andradite component (Udubaşa et al., 1996).

Mesozoic gabrodiabases and diabases in the Marmarosh Massif are a potential source of the basic rock relics (Cr-spinels) in the Malcov deposits. Blocks of basic volcanic material are found embedded in coarse-grained clastic deposits of Late Jurassic and Cretaceous age in the north of Romania and in Ukraine, in the continuation of the Ceahlău Black Flysch (Fore-Marmarosh Suture) units. The Severin-Ceahlău ophiolites and basalts, respectively, are regarded as remnants of an intracontinental oceanic basin situated within the European continental margin (Hoeck et al., 2006, 2009).The Chyvchyn Formation adherent to the Kaminnyi Potik Nappe (Fore-Marmarosh Suture) consists of Late Jurassic basic volcanic rocks (Hnylko et al., 2015b). Tectonic klippen of Jurassic-Early Cretaceous mafic volcanic rocks of both oceanic and continental origin are present at the base of the Burkut Nappe (Lyashkevich et al., 1995). The lower part of the Vezhany Nappe located to the north-west of the Marmarosh Crystalline Massif is represented by an Early Cretaceous $\sim 1.000$ m thick olistostrome with olistoliths of Proterozoic(?)-Paleozoic-Mesozoic rocks derived from the Marmarosh Massif as well as olistoliths of Mesozoic mafic-ultramafic rocks and of Early Cretaceous organogenic Urgonian-type limestones (Hnylko and Hnylko, 2016).

The investigation of heavy mineral associations as well as their chemical composition show that the nature of the source material for the Magura Basin deposits (the Malcov Fm.) during the Eocene to Oligocene did not change significantly. Crystalline rocks still play an important role in the source region. During this period, crystalline complexes of the Dacia Mega-Unit were elevated (e.g., Hnylko, 2011a, c). Albeit burial is indicated for the NW part of the Transylvania Basin (including the Preluca Massif), East and SE Carpathians during Middle Eocene to Oligocene (Merten, 2011; Gröger et al., 2013), small parts of crystalline basement in the northern part of the Eastern Carpathians (as shown by the AHe ages of apatite - cf. Merten, 2011: fig. 6.4D) and Apuseni Mts. (Tisza Mega-Unit) were exhumed (Merten, 2011; Merten et al., 2011). However, it should be noted that the rocks from higher levels of the metamorphic complexes were exposed, and owing to the increased content of carbonate clasts along with the cover sequences or nappes of the Fore-Marmarosh Suture - Kaminnyi Potik, Rakhiv and Burkut (Porkulets), relatively rich in carbonates.

The PKB may have been the source of carbonate detritus (Ďurkovič, 1966; Olszewska and Oszczypko, 2010) but Birkenmajer (1986) inferred that it was buried during the Late Eocene-Early Oligocene. Triassic and Jurassic carbonate rocks included in the Marmarosh Massif and Fore-Marmarosh
Suture (Andrusov, 1936; Lashmanov and Zaydis, 1971; Burov et al., 1986; Hnylko, 2011b, 2012; Hnylko et al., 2015b) appear to be a more probable source, but nevertheless part of the carbonate detritus was derived from Klippen Belt.

The Tisza Mega-Unit is proposed as a potential source for flysch sediments of the Magura Basin (e.g., Oszczypko et al., 2006; Oszczypko and Oszczypko-Clowes, 2009), its lithological composition substantially corresponding to the assumed source rocks - gneisses, mica schists, amphibolites, granitoids and minor calc-silicate rocks and eclogites. The position of the Tisza Mega-Unit during the Eocene and Oligocene (cf. Csontos et al., 1992; Kováč et al., 1994; Csontos, 1995; Csontos and Vörös, 2004; Kovács et al., 2007) and also during the Early Miocene (Kováč et al., 1994; Kovács et al., 2007; Ustaszewski et al., 2008), as well as palaeoflow directions (Koráb and Ďurkovič, 1966; Stráník, 1965; Nemčok and Ďurkovič, 1989; data from this work), indicate this unit as a possible source area mainly for the Krynica Unit. The chemical composition of detrital garnets from the Krynica Unit is similar to that of garnets from crystalline rocks of the Variscan metamorphic basement of the Görcsöny Ridge and/or Békés-Codru Zone which continues to the Apuseni Mountains (Romania) (Árkai et al., 1999; Horváth, 2007); these units are also possible sources for part of the staurolite and tourmaline. High-grade metamorphic complexes (with eclogite occurrences) of the Villány-Bihor Zone seem to be a source for detrital garnets with higher pyrope content. The chemical composition of garnets from eclogite occurrences within orthogneiss host rock in the Jánoshalma High (middle part of the crystalline basement of the Tisza Mega-Unit, Zachar et al., 2007) is the same.

\section{CONCLUSIONS}

1. The Malcov Formation originated in several small-sized sub-basins the axis of which runs in NW-SE (present coordinates in the Eastern Slovakia). The shape and size of sub-basins significantly affected the sedimentation of the clastic deposits. The bulk of the clastic deposits has the character of classic turbidites. These lithofacies were deposited from turbidity currents or concentrated density flows. Very thick beds of greywacke quartz-carbonaceous sandstones with composite lamination originated from large-volume concentrated gravity currents, which were reflected or deflected in flow direction at the edges of sub-basins. Coarse-grained lithofacies were deposited mostly from concentrated density currents.

2. The palaeoflow record is very varied and highlights the contribution of sedimentary material from several directions and/or diversion of gravity currents from the main flow direction (SE-NW). A significant impact was also input of clastic sediments from peripheral parts of sub-basins - structural elevations, which at the time of sedimentation were still below sea level.

3. Analysis of the heavy mineral associations showed a dominance of garnet over zircon, rutile and tourmaline. The heterogeneous chemical composition of garnets and tourmalines is significant as regards metamorphic source rock origin, these being especially low- to medium-grade (rarely high-grade) metasedimentary rocks. Zoned spessartine garnets were derived from low-grade metasedimentary rocks with $\mathrm{Mn}$ mineralisation. Cr-spinels indicate a specifically volcanic origin. Some heavy minerals originated from resedimentation.

4. Following the heavy mineral spectra and palaeoflow analyses, we conclude that the main part of the detrital material forming the Malcov Formation deposits mainly in the Rača Unit was derived from the Marmarosh Massif and Fore-Marmarosh 
Suture. Besides, we infer for the Krynica Unit a significant contribution of detrital material from medium- to high-grade metamorphic complexes of the Villáni-Bihor and Békés-Codru zones (crystalline basement of Tisza Mega-Unit; Fig. 8). The Pieniny Klippen Belt probably also supplied the Malcov sedimentary basin. Part of the clastic material was redeposited from older flysch formations.
Acknowledgements. The research was partly supported by project of Ministry of the Environment of the Slovak Republic - 0306 "Geological map of the Nízke Beskydy Mts. - western part at scale 1:50,000". The authors thank Prof. N. Oszczypko from the Institute of Geological Sciences of the Jagiellonian University and two anonymous reviewers for helpful comments and recommendations. The authors are also grateful to Editor-in-Chief Prof. T.M. Peryt for thorough editorial handling.

\section{REFERENCES}

Andrusov, D., 1936. Geological research of the Subcarpathian Ruthenia in 1932-1934 (in Czech with French summary). Carpathica, 1: 53-110.

Arai, S., 1992. Chemistry of chromian spinel in volcanic rocks as a potential guide to magma chemistry. Mineralogical Magazine, 56: 173-184.

Árkai, P., Horváth, P., Nagy, G., 1999. A clockwise P-T path from the Variscan basement of the Tisza Unit, Pannonian Basin, Hungary. Geologica Croatica, 52: 109-117.

Aubrecht, R., Méres, Š., Sýkora, M., Mikuš, T., 2008. Composition of garnet and spinel from the Aptian/Albian sediments of the Czorsztyn Unit and their possible provenance (in Slovak with English summary). In: Conference "Cambelove dni 2008" (ed. L'. Jurkovič): 14-16. Abstract book, Comenius University of Bratislava.

Aubrecht, R., Méres, Š., Sýkora, M., Mikuš, T., 2009. Provenance of the detrital garnets and spinels from the Albian sediments of the Czorsztyn Unit (Pieniny Klippen Belt, Western Carpathians, Slovakia). Geologica Carpathica, 60: 463-483.

Báldi, T., 1980. The early history of the Paratethys. Földtani Kőzlöny - Bulletin of the Hungarian Geological Society, 110: 456-472.

Báldi, T., 1984. The terminal Eocene and early Oligocene events in Hungary and the separation of an anoxic, cold Paratethys. Eclogae Geologicae Helvetiae, 77: 1-27.

Baldwin, J.R., Von Knorring, O., 1983. Compositional range of $\mathrm{Mn}$-garnet in zoned granitic pegmatites. Canadian Mineralogist, 21: 683-688.

Basu, A., Young, S., Suttner, L.J., James, W.C., Mack, C.H., 1975 Reevaluation of the use of undulatory extinction and polycrystallinity in detrital quartz for provenance interpretation. Journal of Sedimentary Petrology, 45: 873-882.

Birkenmajer, K., 1986. Stages of structural evolution of the Pieniny Klippen Belt, Carpathians. Studia Geologica Polonica, 88: 7-32.

Birkenmajer, K., Oszczypko, N., 1989. Cretaceous and Paleogene lithostratigraphic units of the Magura Nappe, Krynica Subunit, Carpathians. Annales Societatis Geologorum Poloniae, 59 145-181.

Blaicher, J., Sikora, W., 1967. Stratigraphy of the Richvald Unit in Leluchów (in Polish). Kwartalnik Geologiczny, 11 (4): 453-454.

Bónová, K., Kováčik, M., Bóna, J., Derco, J., 2009a. Detritic garnets from sediments of the Magura Unit in Eastearn part of Flysch Belt (Western Carpathians) - chemical composition and provenance (in Slovak). Mineralia Slovaca (Geovestník), 41 91-92.

Bónová, K., Kováčik, M., Bóna, J., 2009b. Detritic garnets, tourmalines and zircons from the Makovica Sandstones of the Rača Unit from the Eastern-Slovakian part of Flysch Belt (Western Carpathians): chemical composition and provenance (in Slovak). In: Spoločný geologický kongres Českej a Slovenskej geologickej spoločnosti (eds. M. Kohút and L. Šimon): 27-28. Konferencie, sympóziá, semináre, Štátny geologický ústav D. Štúra, Bratislava.

Bónová, K., Bóna, J., Kováčik, M., Siráňová, Z., 2010a. Detritic garnets, tourmalines and zircons from the Strihovce Formation of the Krynica Unit (Magura Nappe): their chemical composition and possible origin (in Slovak). In: Geochémia 2010: zborník vedeckých príspevkov z konferencie (eds. I. Slaninka, L'. Jurkovič and O. Ďurža): 29-32. Štátny geologický ústav D. Štúra, Bratislava.

Bónová, K., Kováčik, M., Bóna, J., Siráňová, Z., 2010b. Contribution to knowledge of the Malcov Formation provenance (Magura Nappe, Eastern Slovakia) based on detrital heavy minerals study (in Slovak). In: Geochémia 2010: zborník vedeckých príspevkov z konferencie (eds. I. Slaninka, L'. Jurkovič and O. Duurža): 151-152. Štátny geologický ústav D. Štúra, Bratislava.

Bouma, A.H., 1962. Sedimentology of some flysch deposits: a graphic approach to facies interpretation. Elsevier, Amsterdam.

Burkhard, D.J.M., 1993. Accessory chromium spinels: their coexistence and alteration in serpentinites. Geochimica et Cosmochimica Acta, 57: 1297-1306.

Burov, V.S., Vithniakov, I.B., Glushko, V.V., Dosin, G.D., Kruglov S.S., Kuzovenko, V.V., Sviridenko, V.G., Smirnov, S.E., Sovtzik, I.V., Utrobin, V.N., Thakin, V.A., 1986. Tektonika Ukrainskykh Karpat. Ministerstvo Geologii Ukrainskoj SSR, Kiev.

Cieszkowski, M., Olszewska, B., 1986. Malcov beds in the Magura Nappe near Nowy Targ. Annales Societatis Geologorum Poloniae, 56: 53-71.

Contescu, L., Jipa, D., Mihailescu, N., Panin, N., 1966. The Internal Paleogene flysch of the Eastern Carpathians: paleocurents, source areas and facies significance. Sedimentology, 7: 307-321.

Corfu, F., Hanchar, J.M., Hoskin, P.W.O., Kinny, P., 2003. Atlas of zircon textures. Reviews in Mineralogy and Geochemistry, 53: 469-500.

Csontos, L., 1995. Tertiary tectonic evolution of the Intra-Carpathian area. Acta Vulcanologica, 7: 1-14.

Csontos, L., Vörös, A., 2004. Mesozoic plate tectonic reconstruction of the Carpathian region. Palaeogeography, Palaoclimatology, Palaeoecology, 210: 1-56.

Csontos, L., Nagymarosy, A., Horváth, F., Kovác, M., 1992. Tertiary evolution of the Intra-Carpathian area: a model. Tectonophysics, 208: 221-241.

DeCelles, P.G., Gilles, K.A., 1996. Foreland basin systems. Basin Research, 8: 105-123.

Deer, W.A., Howie, R.A., Zussman, J., 1982. Rock-forming minerals vol. 1A, Orthosilicates. 2nd ed. Longman Group Limited, England.

Deer, W.A., Howie, R.A., Zussman, J., 1992. An Introduction to the Rock-Forming Minerals. Longman, 2nd. Edition.

Dick, H.J.B., Bullen, T., 1984. Chromian spinel as a petrogenetic indicator in abyssal and alpine-type peridotites and spatially associated lavas. Contribution to Mineralogy and Petrology, 86: 54-76.

Dickinson, W.R., 1985. Interpreting provenance relations from detrital modes of sandstones. In: Provenance of Arenites (ed. G.G. Zuffa): 333-363. Reidel, Dordrecht. 
Duurkovič, T., 1965. Heavy minerals study in the Dukla folds and Rača Unit of the Magura Flysch in Eastearn Slovakia (in Slovak). Zprávy o Geologických výzkumech v r. 1964, čas II: 73-74. Bratislava.

Durkovič, T., 1966. East Slovakian Flysch sediments. Sborník geologických vied, Západné Karpaty, 6: 107-154.

Fejdiová, O., 1990. Heavy mineral associations from Zborov-1 borehole (in Slovak). Partial technical report. Archív Štátneho geologického ústavu D. Štúra, Bratislava.

Gạgała, Ł., Vergés, J., Saura, E., Malata, T., Ringenbach, J.-C., Werner, P., Krzywiec, P., 2012. Architecture and orogenic evolution of the northeastern Outer Carpathians from cross-section balancing and forward modeling. Tectonophysics, 532-535: 223-241.

Garzanti, E., Doglioni, C., Vezzoli, G., Ando, S., 2007. Orogenic belts and orogenic sediment provenance. The Journal of Geology, 115: 315-334.

Geological map of Slovakia at scale 1:50 000, 2013. Bratislava: Štátny geologický ústav Dionýza Štúra, 2013. [cit. 18. 03. 2015] Available on the internet: http://mapserver.geology.sk/gm50js/

Green, T.H., 1977. Garnet in silicic liquids and its possible use as P-T indicator. Contributions to Mineralogy and Petrology, 65: 59-67.

Gröger, H.R., Tischler, M., Fügenschuh, B., Schmid, S.M., 2013. Thermal history of the Maramures area (Northern Romania) constrained by zircon fission track analysis: Cretaceous metamorphism and Late Cretaceous to Paleocene exhumation. Geologica Carpathica, 64: 383-398.

Grzebyk, J., Leszczyński, S., 2006. New data on heavy minerals from the Upper Cretaceous-Paleogene flysch of the Beskid Śląski Mts. (Polish Carpathians). Geological Quarterly, 50 (2): 265-280.

Handy, M.R., Ustaszewski, K., Kissling, E., 2014. Reconstructing the Alps-Carpathians-Dinarides as a key to understanding switches in subduction polarity, slab gaps and surface motion. International Journal of Earth Sciences, 104: 1-26.

Henry, D.J., Dutrow, B.L., 1992. Tourmaline in a low grade clastic metasedimentary rock: an example of the petrogenetic potential of tourmaline. Contributions to Mineralogy and Petrology, 112: 203-218.

Henry, D.J., Dutrow, B.L., 1996. Metamorphic tourmaline and its petrologic applications. Reviews in Mineralogy, 33: 503-557.

Henry, D.J., Guidotti, C.V., 1985. Tourmaline as a petrogenetic indicator mineral: An example from the staurolite-grade metapelites of NW Maine. American Mineralogist, 70: 1-15.

Henry, D.J., Novák, M., Hawthorne, F.C., Ertl, A., Dutrow, B.L., Uher, P., Pezzotta, F., 2011. Nomenclature of the tourmaline-supergroup minerals. American Mineralogist, 96: 895-913.

Hnylko, O., 2011a. Terrane analysis and geological evolution of the Carpathians (in Ukrainian with English summary). Visnyk of the Lviv University, Geological Series, 25: 174-188.

Hnylko, O.M., 2011b. Tectonic zoning of the Carpathians in terms of the terrane tectonics. Section 1. Main units of the Carpathian Building (in Ukrainian with English summary). Geodynamika, 10: $47-57$

Hnylko, O., 2011c. Geologic evolution of the Carpathians in the light of the terrane analysis (in Ukrainian with English summary) Geodynamika, 11: 64-65.

Hnylko, O.M., 2012. Tectonic zoning of the Carpathians in terms of the terrane tectonics. Article 2. The Flysch Carpathians - ancient accretionary prism (in Ukrainian with English summary). Geodynamika, 12: 67-78.

Hnylko, O.M., Generalova, L.V., 2014. Tectonic-sedimentary evolution of the Fore-Marmarosh accretionary prism of the Ukrainian Flysch Carpathians (in Russian with English summary). Vestnik of Saint Petersburg University, series 7, Geology, 2: 5-23.

Hnylko, O.M., Hnylko, S.R., Generalova, L.V., 2015a. Formation of the structure of the Klippen zones and the interklippen flysch of inner Ukrainian Carpathians - results of convergence and collision of microcontinental terranes (in Russian with English summary). Vestnik of Saint Petersburg University, series 7, Geology, 2: 4-24.

Hnylko, O., Krobicki, M., Feldman-Olszewska, A, Iwańczuk, J., 2015b. Geology of the volcano-sedimentary complex of the Kaminnyi Potik Unit on Chyvchyn Mountain (Ukrainian Carpathians): preliminary results. Geological Quarterly, 59 (1): 145-156.

Hnylko, S., Hnylko, O., 2016. Foraminiferal stratigraphy and palaeobathymetry of Paleocene-lowermost Oligocene deposits (Vezhany and Monastyrets nappes, Ukrainian Carpathians). Geological Quarterly, 60 (1): 77-105.

Hoeck, V., Ionescu, C., Koller, F., 2006. Mesozoic ophiolites in the Dinarides and the Carpathians: a review. Acta Mineralogica-Petrographica, Abstract-Series 5: 39-41.

Hoeck, V., Ionescu, C., Balintoni, I., Koller, F., 2009. The Eastern Carpathians "ophiolites" (Romania): remnans of a Triassic ocean. Lithos, 108: 151-171.

Horváth, P., 2007. PT pseudosections in KFMASH, KMnFMASH, NCKFMASH and NCKMnFMASH systems: a case study from garnet-staurolite mica schist from the Alpine metamorphic basement of the Pannonian Basin (Hungary). Geologica Carpathica, 58: 107-119.

Hoskin, P.W.O., Schaltegger, U., 2003. The composition of zircon and igneous and metamorphic petrogenesis. Reviews in Mineralogy and Geochemistry, 53: 27-62.

Hubert, J.F., 1962. A zircon-tourmaline-rutile maturity index and the interdependence of the composition of heavy mineral assemblages with the gross composition and texture of sandstones. Journal of Sedimentary Petrology, 32: 440-450.

Hurai, V., Marko, F., Tokarski, A. K., Świerczewska, A., Kotulová, J., Biroň, A., 2006. Fluid inclusion evidence for deep burial of the Tertiary accretionary wedge of the Carpathians. Terra Nova, 18: $440-446$.

Jurewicz, E., 2005. Geodynamic evolution of the Tatra Mts. and the Pieniny Klippen Belt (Western Carpathians): problems and comments. Acta Geologica Polonica, 55: 295-338.

Kamenetsky, V.S., Crawford, A.J., Meffre, S., 2001. Factors controlling chemistry of magmatic spinel; an empirical study of associated olivine, $\mathrm{Cr}$-spinel and melt inclusions from primitive rocks. Journal of Petrology, 42: 655-671.

Kanungo, D.R., Malpe, D.B., Leake, B.E., 2014 Manganocummingtonite from Mesoproterozoic, Sausar Fold Belt, Central India. Journal of Geological Society of India, 84: 93-99.

Királi, E., Török, K., 2003. Magmatic garnet in deformed aplite dykes from the Mórágy granitoid, SE-Transdanubia, Hungary. Acta Geologica Hungarica, 46: 239-254.

Koráb, T., 1983. Geological map of the Nízke Beskydy Mts. - eastern part at scale 1:50,000. Geological Institute of Dionýz Štúr, Bratislava.

Koráb, T., Ďurkovič, T., 1966. Sedimentary petrografy analysis of heavy minerals from Cirocha, Údava, and Výrava rivers alluvia in the flysch of Eastern Slovakia (in Slovak with English sumary). Geologické práce, Zprávy, 38: 79-86.

Koráb, T., Ďurkovič, T., 1973. Sedimentology and paleogeography of Submenilite beds of Dukla Unit. Geologické Práce, Správy, 60: 85-120.

Koráb, T., Ďurkovič, T., 1978. Geology of Dukla Unit (East-Slovakian Flysch) (in Slovak with English summary). Publ. Geological Institute of Dionýz Štúr, Bratislava.

Koráb, T., Nemčok, J., Ďurkovič, T., Marschalko, R., 1962. General investigation of oriented sedimentary structures in East-Slovakian Flysch (in Slovak with English summary). Geologický sborník, 13: 257-274.

Kovács, I., Csontos, L., Szabó, Cs., Bali, E., Falus, Gy., Benedek, K., Zajacz, Z., 2007. Paleogene-early Miocene igneous rocks and geodynamics of the Alpine-Carpathian-Pannonian-Dinaric region: an integrated approach. GSA Special Paper, 418: 93-112.

Kováč, M., Král', J., Márton, E., Plašienka, D., Uher, P., 1994. Alpine uplift history of the Central Western Carpathians: geo- 
chronological, paleomagnetic, sedimentary and structural data. Geologica Carpathica, 45: 83-96.

Kováčik, M., ed., Bóna, J., Gazdačko, L'., Kobulský, J., Maglay, J., Kučera, M., 2011. Geological map of the Nízke Beskydy Mts. - western part at scale 1:50 000. Ministry of the Environment of the Slovak Rep., State Geological Institute of Dionýz Štúr, Bratislava.

Kováčik, M., ed., Bóna, J., Gazdačko, L'., Kobulský, J., Maglay, J., Žecová, K., Derco, J., Zlinská, A., Siráňová, Z., Boorová, D., Bónová, K., Buček, S., Kucharič, L'., Kubeš, P., Bačová, N., Petro, L'., Vaněková, H., 2012. Explanation to the geological map of the Nízke Beskydy Mts. - western part at scale 1:50 000. State Geological Institute of Dionýz Štúr, Bratislava.

Kropáč, K., 2012. Mineralogy and genesis of banded iron ores of the Desná Crystalline Complex (in Czech). Ph.D. thesis. Masarykova universita, Brno.

Lashmanov, V.I., Zaydis, B.B., 1971. Geologiya i geokhronologiy apiznoyurskikh vidkladiv Marmaroshskogo masivu. Geologichnyj zhurnal, 31: 55-66.

Lenaz, D., Kamenetsky, V.S., Crawford, A.J., Princivalle, F., 2000. Melt inclusions in detrital spinel from the SE Alps (Italy-Slovenia): a new approach to provenance studies of sedimentary basins. Contribution to Mineralogy and Petrology, 139 748-758.

Lenaz, D., Winkler, W., Reusser, E., Princivalle, F., 2001. Preliminary chemical data of detrital Cr-spinels from Polish Western Carpathians Flysch. In: Abstracts of 21st meeting IAS 2001, Davos (Switzerland).

Lenaz, D., Mazzoli, C., Spišiak, J., Princivalle, F., Maritan, L., 2009. Detrital Cr-spinel in the Šambron-Kamenica Zone (Slovakia): evidence for an ocean-spreading zone in the Northern Vardar suture? International Journal of Earth Sciences, 98: 345-355.

Leszczyński, S., 1997. Origin of the sub-menilite Globigerina mar (Eocene-Oligocene transition) in the Polish Outer Carpathians. Annales Societatis Geologorum Poloniae, 67: 367-427.

Leszczyński, S., Malata, E., 2002. Sedimentary conditions in the Siary Zone of the Magura Basin (Carpathians) in the late Eocene-early Oligocene. Annales Societatis Geologorum Poloniae, 72: 201-239.

Leško, B., 1960. Paleogene of the Klippen Belt in Eastern Slovakia (in Slovak with German summary). Geologický sborník, 11: 95-103.

Leško, B., Samuel., O., 1968. Geology of the Eastern-Slovakian Flysch (in Slovak with English summary). Slovenská akadémia vied, Bratislava.

Leško, B., Ďurkovič, T., Číčel, B., 1959. Traces of Paleogene volcanism of Eastern Slovakia (in Slovak with English summary). Geologické práce, Správy, 16: 131-142.

Lexa, J., Bezák, V., Elečko, M., Mello, J., Polák, M., Potfaj, M., Vozár, J., ed., Schnabel, G. W., Pálenský, P., Császár, G., Ryłko, W., Mackiv, B., co-ed., 2000. Geological map of Western Carpathians and adjacent areas $(1: 500,000)$. Bratislava, Ministry of Environment of Slovak Republic, Geological Survey of Slovak Republic.

Lužar-Oberiter, B., Mikes, T., von Eynatten, H., Babic, L., 2009 Ophiolitic detritus in Cretaceous clastic formations of the Dinarides (NW Croatia): evidence from Cr-spinel chemistry. International Journal of Earth Sciences, 98: 1097-1108.

Lyashkevich, Z.M., Medvedev, A.P., Krupskiy, Y.Z., Varitchev, A.S., Timoschuk, V.R., Stupka, O.O., 1995. Tectonomagmatic Evolution of Carpathians (in Russian with English summary) Naukovaya Dumka, Kiev.

Mange, M.A., Morton, A.C., 2007. Geochemistry of heavy minerals. Developments in Sedimentology, 58: 345-391.

Manning, D.A.C., 1983. Chemical variations of garnets from aplites and pegmatites, peninsular Thailand. Mineralogical Magazine, 47: $353-358$.

Martínek, K., Štolfová, K., 2009. Provenance study of Permian non-marine sandstones and conglomerates of the Krkonoše Piedmont Basin (Czech Republic): exotic marine limestone peb- bles, heavy minerals and garnet composition. Bulletin of Geosiences, 84: 555-568.

Matkovskyi, O., 1971. Mineralogiya i petrografiya Chivchinskich gor (Ukrainskiye Karpaty) (in Russian). Izdatelstvo Lvovskogo universiteta, Lvov.

Matkovskyi, O., Kvasnytsya, V., Naumko, I., Bilonizhka, P., Hrechanovska, O., Kvasnytsya, I., Melnikov, V., Popp, I., Skakun, L., Slyvko, Ye., Slovotenko, N., Bondar, R., Manchur, B., Matviishyn, Z., Shemyakina, T., 2011. Minerals of Ukrainian Carpathians. Silicates (in Ukrainian with English summary). LNU imeni Ivana Franka Lviv.

Márton, E., Tischler, M., Csontos, L., Fügenschuh, B., Schmid, S.M., 2007. The contact zone between the ALCAPA and Tisza-Dacia mega-tectonic units of Northern Romania in the light of new paleomagnetic data. Swiss Journal of Geosciences, 100: 109-124.

Márton, E., Grabowski, J., Plašienka, D., Túnyi, I., Krobicki, M., Haas, J., Pethe, M., 2013. New paleomagnetic results from the Upper Cretaceous red marls of the Pieniny Klippen Belt, Western Carpathians: Evidence for general CCW rotation and implications for the origin of the structural arc formation. Tectonophysics, 592: 1-13.

Melcher, F., 1995. Genesis of chemical sediments in Birimian greenstone belts: evidence from gondites and related manganese-bearing rocks from northern Ghana. Mineralogical Magazine, 59: 229-251.

Merten, S., 2011. Thermo-tectonic evolution of a convergent orogen with low topographic build-up: exhumation and kinematic patterns in the Romanian Carpathians derived from thermochronology. Amsterdam, Ipskamp Drukkers B. V.

Méres, Š., 2008. Garnets - important information resource about source area and parental rocks of the siliciclastic sedimentary rocks (in Slovak with English abstract). In: Conference "Cambelove dni 2008" (ed .L. Jurkovič): 37-43. Abstract book, Comenius University of Bratislava.

Merten, S., Matenco, L., Foeken, J.P.T., Andriessen, P.A.M., 2011. Toward understanding the post-collisional evolution of an orogen influenced by convergence at adjacent plate margins: Late Cretaceous-Tertiary thermotectonic history of the Apuseni Mountains. Tectonics, 30: 1-28.

Mikuš, T., Spišiak, J., 2007. Chemical composition and alteration of Cr-spinels from Meliata and Penninic serpentinized peridotites (Western Carpathians and Eastern Alps). Geological Quarterly, 51 (3): 257-270.

Mikuš, T., Spišiak, J., Sýkora, M., Demko, R., 2006. Chemical composition of spinels from Mesozoic alcali basalts of the Western Carpathians: implications for sources of detrital spinels in flysch sediments. Geologica Carpathica, 57: 447-460.

Miyashiro, A., 1955. Pyralspite garnets in volcanic rocks. Journal of the Geological Society of Japan, 61: 463-470.

Mohapatra, B.K., Nayak, B., 2005. Petrology of Mn carbonate-silicate rocks from the Gangpur Group, India. Journal of Asian Earth Sciences, 25: 773-780.

Morton, A.C., 1984. Stability of detrital heavy minerals in Tertiary sandstones of the North Sea Basin. Clay Minerals, 19: 287-308.

Morton, A.C., 1987. Influences of provenance and diagenesis on detrital garnet suites in the Paleocene Forties Sandstone, Central North Sea. Journal of Sedimentary Petrology, 57: 1027-1032.

Morton, A.C., Hallsworth, C.R., 1994. Identifying provenance-specific features of detrital heavy mineral assemblages in sandstones. Sedimentary Geology, 90: 241-256.

Morton, A.C., Hallsworth, C.R., 1999. Processes controlling the composition of heavy mineral assemblages in sandstones. Sedimentary Geology, 124: 3-29.

Morton, A.C., Hallsworth, C.R. 2007. Stability of detrital heavy minerals during burial diagenesis. Developments in Sedimentology, 58: 215-245.

Morton, A.C., Hallsworth, C.R., Chalton, B., 2004. Garnet compositions in Scottish and Norwegian basement terrains: a frame- 
work for interpretation of North Sea sandstone provenance. Marine and Petroleum Geology, 21: 393-410.

Morton, A.C., Whitham, A.G., Fanning, C.M., 2005. Provenance of Late Cretaceous-Paleocene submarine fan sandstones in the Norwegian Sea: integration of heavy mineral, mineral chemical and zircon age data. Sedimentary Geology, 182: 3-28.

Mulder, T., Alexander, J., 2001. The physical character of subaqueous sedimentary density flows and their deposits. Sedimentology, 48: 269-299.

Nemčok, J., 1961. Origin and filling of the Magura flysch depressions in the Eastern Slovakia (in Slovak with German summary). Geologický Sborník Slovenskej Akadémie Vied, 12: 175-190.

Nemčok, J., 1990. Geological map of the Pieniny, Čergov, L'ubovnianska and Ondavská vrchovina highlands at scale 1:50,000. State Geological Institute of Dionýz Štúr, Bratislava.

Nemčok, J., Ďurkovič, T., 1989. Litology of Malcov Member in Magura Unit (East Slovakia) (in Slovak with English summary). Geologické Práce, Správy, 89: 39-51.

Nemčok, J., Koráb, T., 1963. Contribution to the geology of Smilno tectonic Windows and adjacent part of the Magura flysch. Geologický sborník, 16: 209-215.

Nemčok, J., ed., Zakovič, M., Gašpariková, V., Ďurkovič, T. Snopková, P., Vrána, K., Hanzel, V., 1990. Explanation to the geological map of the Pieniny, Čergov, L'ubovnianska and Ondavská vrchovina highlands at scale 1:50,000 (in Slovak with English summary). State Geological Institute of Dionýz Štúr, Bratislava.

Olszewska, B., Oszczypko, N., 2010. The geological position, sedimentary record and composition of the Tylicz Conglomerate (Late Eocene-Oligocene): stratigraphical and paleogeographical implications (Magura Nappe, Polish Outer Carpathians). Geologica Carpathica, 61: 39-54.

Ori, G.G., Friend, P.G., 1984. Sedimentary basins formed and carried piggyback on the active thrust sheets. Geology, 12: 475-478.

Oszczypko, N., 1973. The geology of the Nowy Sacz Basin (the Middle Carpathians) (in Polish with English summary). Biuletyn Institutu Geologicznego, 271: 101-197.

Oszczypko, N., 2004. The structural position and tectonosedimentary evolution of the Polish Outer Carpathians. Przegląd Geologiczny, 52: 780-792.

Oszczypko, N., 2006. Late Jurassic-Miocene evolution of the Outer Carpathian fold-and-trust belt and its foredeep basin (Western Carpathians, Poland). Geological Quarterly 50 (1): 169-194.

Oszczypko, N., Oszczypko-Clowes, M., 2006. Evolution of the Magura Basin. In: Palaeotectonic Evolution of the Outer Carpathian and Pieniny Klippen Belt Basins (eds. N. Oszczypko, A. Uchman and E. Malata): 133-164. Instytut Nauk Geologicznych Uniwersytetu Jagiellońskiego, Kraków.

Oszczypko, N., Oszczypko-Clowes, M., 2009. Stages in the Magura Basin: a case study of the Polish sector (Western Carpathians), Geodinamica Acta, 22: 83-100.

Oszczypko, N., Salata, D., 2004. Position of the Late Cretaceous Palaeocene source areas of the Magura Basin - evidence from heavy mineral study. Geolines, 17: 76-77.

Oszczypko, N., Salata D., 2005. Provenance analyses of the Late Cretaceous-Paleocene deposits of the Magura basin (Polish Western Carpathians) - evidence from a study of the heavy minerals. Acta Geologica Polonica, 55: 237-267.

Oszczypko, N., Oszczypko-Clowes, M., Golonka J., Marko, F., 2005a. Oligocene-Lower Miocene sequences of the Pieniny Klippen Belt and adjacent Magura Nappe between Jarabina and the Poprad River (East Slovakia and South Poland): their tectonic position and palaeogeographic implications. Geological Quarterly, 49 (4): 379-402.

Oszczypko, N., Oszczypko-Clowes, M., Golonka, J., Krobicki, M., 2005b. Position of the Marmarosh Flysch (Eastern Carpathians) and its relation to the Magura Nappe (Western Carpathians). Acta Geologica Hungarica, 48: 259-282.

Oszczypko, N., Oszczypko-Clowes, M., Salata, D., 2006. Exotic rocks of the Krynica Zone (Magura Nappe) and their palageographic significance (in Polish). Geologia, 32: 21-45.
Oszczypko, N., Jurewicz, E., Plašienka, D., 2010. Tectonics of the Klippen Belt and Magura Nappe in the eastern part of the Pieniny Mts. (Western Carpathians, Poland and Slovakia). Geologica Balcanica, 39: 279.

Oszczypko, N., Ślączka, A., Oszczypko-Clowes, M., Olszewska, B., 2015. Where was the Magura Ocean? Acta Geologica Polonica, 65: 319-344.

Oszczypko-Clowes, M., 2001. The nannofossil biostratigraphy of the youngest deposits of the Magura Nappe (east of the Skawa river, Polish Flysch Carpathians). Annales Societatis Geologorum Poloniae, 71: 139-188.

Oszczypko-Clowes, M., Zydek, B., 2012. Paleoecology of the Upper Eocene-Lower Oligocene Malcov Basin based on the calcareous nannofossils: a case study of the Leluchów section (Krynica Zone, Magura Nappe, Polish Outer Carpathians). Geologica Carpathica, 63: 149-164.

Otava, J., Krejčí, O., Sulovský, P., 1997. First results of electron microprobe analysis of detrital garnets from the Rača Unit of the Magura Group (in Czech with English abstract). Geologické výzkumy na Moravě a ve Slezku v roce 1996: 39-42.

Otava, J., Sulovský, P., Krejčí, O., 1998. The results of study the detrital garnets from the Cretaceous sediments of the Rača Unit of the Magura Group (Outer Carpathians) (in Czech). Geologické výzkumy na Moravě a ve Slezku v roce 1997: 29-31.

Pettijohn, F.J., Potter, P.E., Siever, S., 1972. Sand and Sandstone. Springer, New York.

Pickering, K.T., Stow, D.A.V., Watson, M.P., Hiscott, R.A., 1986. Deep-water facies, processes and models: a review and classification scheme for modern and ancient sediments. Earth-Science Reviews, 23: 75-174.

Plašienka, D., 2011. The Pieniny Klippen Belt - structure, evolution and position in the Carpathian tectonoc framework. Geologické Výzkumy Moravy a Slezka: 39-44. The Open Congress ČGS and SGS, September 22-25, 2011, Monínec.

Plašienka, D., Mikuš, V., 2010. Geological setting of the Pieniny and Šariš sectors of the Klippen Belt between Litmanová and Drienica villages in the eastern Slovakia (in Slovak with English summary). Mineralia Slovaca, 42: 155-178.

Plašienka, D., Soták, J., 2015. Evolution of Late Cretaceous-Palaeogene synorogenic basins in the Pieniny Klippen Belt and adjacent zones (Western Carpathians, Slovakia): tectonic controls over a growing orogenic wedge. Annales Societatis Geologorum Poloniae, 85: 43-76.

Potfaj, M., 1983. Magura sandstones and Malcov Beds in Orava Region (in Slovak with English summary). Geologické Práce, Správy, 79: 117-140.

Potfaj, M., 1998. Geodynamics of the Klippen Belt and Flysch Belt of the Western Carpathians. In: Geodynamic development of the Western Carpathians (ed. M. Rakús): 143-154. Geological Survey of Slovak Republic, Bratislava.

Potfaj, M., Samuel, M., Raková, J., Samuel, O., 1991. Geological structure of the Kubínska hol'a range (Orava) (in Slovak with English summary). Západné Karpaty, Séria Geológia, 15: 25-66.

Potfaj, M., Kováčik, M., eds., Bóna, J., Žec, B., Pristaš, J., Maglay, J., 2008. General geological map of the Slovak Republic 1:200,000, Map sheet 27 - Svidník. Publ. Ministry of the Environment of the Slovak Republic and State Geological Institute of D. Štúr, Bratislava.

Power, M.R., Pirrie, D., Andersen, J.C.Ø., Wheeler, P.D., 2000. Testing the validity of chromian spinel chemistry as a provenance and petrogenetic indicator. Geology, 28: 1027-1030.

Rastochinskaya, N.S., Nikulina, T.V., Zaldak, A.l., Tserednichenko, V.V., Romanovskaya, I.L., Zukov, D.M., 1981. Geologicheskaya karta SSSR. Masshtab 1:1000 000 (Novaya seriya), Obyasnitenaya zapiska. List M - (34), (35) Lvov, Ministerstvo Geologii SSSR, VSEGEI, Leningrad.

Salata, D., 2002a. Provenance of chromian spinels of the Szczawnica (Magura Nappe) and the Jarmuta (Pieniny Klippen Belt) Formations in the light of their chemical composition. Geologica Carpathica, spec. issue. Proceedings of XVII Con- 
gress of Carpathian-Balkan Geological Association Bratislava, September 1st-4th, 2002.

Salata, D., 2002b. Provenance of heavy minerals of the Jarmuta and Szczawnica Formations (Polish Flysch Carpathians) Geologica Carpathica, spec. issue. Proceedings of XVII Congress of Carpathian-Balkan Geological Association Bratislava, September 1st-4th, 2002

Salata, D., 2004. Detrital garnets from the Upper Cretaceous-Paleogene sandstones of the Polish part of the Magura nappe and the Pieniny Klippen Belt: Chemical constrains. Annales Societatis Geologorum Poloniae, 74: 351-364.

Salata, D., 2013. Garnet provenance in mixed first-cycle and polycycle heavy-mineral assemblages of the Ropianka and Menilite formations (Skole Nappe, Polish Flysch Carpathians): constraints from chemical composition and grain morphology. Annales Societatis Geologorum Poloniae, 83: 161-177.

Salata, D., 2014a. Detrital tourmaline as an indicator of source rock lithology: an example from the Ropianka and Menilite formations (Skole Nappe, Polish Flysch Carpathians). Geological Quarterly, 58 (1): 19-30.

Salata, D., 2014b. Advantages and limitations of interpretations of external morfology of detrital zircon: a case study of the Ropianka and Menilite Formations (Skole Nappe, Polish Flysch Carpathians). Annales Societatis Geologorum Poloniae, 84 153-165.

Salata, D., Oszczypko, N., 2000. Provenance of tourmalines from the Kanina beds (Magura nappe, Polish Flysch Carpathians). Slovak Geological Magazine, 6: 165-167.

Salata, D., Uchman, A., 2012. Heavy minerals from Oligocene sandstones of the Menilite Formation of the Skole Nappe, SE Poland: a tool for provenance specification. Geological Quarterly, 56 (4): 803-820.

Salata, D., Uchman, A., 2013. Conventional and high-resolution heavy mineral analyses applied to flysch deposits: comparative provenance studies of the Ropianka (Upper Cretaceous-Paleocene) and Menilite (Oligocene) formations (Skole Nappe, Polish Carpathians). Geological Quarterly, 57 (4): 649-664

Samuel, O., 1990. Unification of the lithostratigraphic units of the Eastearn-Slovakian flysch (in Slovak). Geologické Práce, Správy, 91: 61-74.

Săndulescu, M., Bercia, I., 1974. Rumanian Carpathians. East Carpathians - Crystalline - Mesozoic Zone. In: Tectonics of the Carpathian Balkan Regions (ed. M. Mahel'): 240-253. Geological Institute of Dionýz Štúr, Bratislava.

Scavnicar, B., 1979. Pjescenjaci Pliocena i Miocena savske potoline. Zbornik Radova, Sekcija za Primljenu Geologiju, Geofiziku, Geokemiju, Serija A 6: 351-382.

Schmid, S.M., Bernoulli, D., Fügenschuh, B., Matenco, L., Schefer, S., Schuster, R., Tischler, M., Ustaszewski, K., 2008. The Alpine-Carpathian-Dinaridic orogenic system: correlation and evolution of tectonic units. Swiss Journal of Geosciences, 101: 139-183.

Ślączka, A., 2005. Bukowiec Ridge: a cordillera in front of the Dukla Basin (Outer Carpathians). Mineralia Slovaca, 37: 255-256.

Ślączka, A., Kruglow, S., Golonka, J., Oszczypko, N., Popadyuk, I., 2006. The general geology of the Outer Carpathians, Poland Slovakia and Ukraine. AAPG Memoir, 84: 221-258.

Soták, J., 2010. Paleoenvironmental changes across the Eocene-Oligocene boundary: insights from the Central-Carpathian Paleogene Basin. Geologica Carpathica, 61: 393-418.

Soták, J., Bebej, J., 1996. Serpentinitic sandstone from the Šambron-Kamenica zone in Eastern Slovakia: evidence of deposition in a Tertiary collisional belt. Geologica Carpathica, 47 227-238.

Soták, J., Križáni, I., Spišiak, J., 1990. On position and material composition of the Mernik conglomerates (the Central Carpathian Paleogene). Acta Geologica Universitates Comenianae, Geologica, 45: 117-125.

Soták, J., Križáni, I., Spišiak, J., 1991. Stratigraphic position and sedimentology of the Merník conglomerates (in Slovak) Geologické Práce, Správy, 92: 53-69.
Soták, J., Biroň, A., Kotulová, J., Rudinec, R., Spišiak, J., 1995. Geological structure of the East Slovakian basin basement in the light of facts and regional tectonic context (in Slovak with English summary). Mineralia Slovaca, 27: 1-8.

Soták, J., Biroň, A., Prokešová, R., Spišiak, J., 2000. Detachment control of core complex exhumation and back-arc extension in the East Slovakian Basin. Slovak Geological Magazine, 6: 130-132.

Soták, J., Biroň, A., Dunkl, I., Lebedev, V., Magyar, J., Prokešová, R., 2005. Synthesis of knowledge about lňačovce Unit: Lithostratigraphic, metamorphic, geochronologic and structural-tectonic data (in Slovak with English abstract). Mineralia Slovaca, 37: 209-213.

Spišiak, J., Hovorka, D., Rybka, R., Turan, J., 1989. Spessartine and piemontite in Lower Palaeozoic metasediments of the Inner West Carpathians (in Slovak with English summary). Časopis pro mineralogii a geologii, 34: 17-32.

Spišiak, J., Soták, J., Magyar, J., Rojkovič, I., 2000. Ultrabasites from the East Slovakian basin basement. Mineralia Slovaca, 32: 305-306.

Spišiak, J., Soták, J., Biroň, A., Mikuš, T., 2001. Cr-spinels from serpentinitic sandstone of the Šambron Zone (Eastern Slovakia) (in Slovak with English summary). Mineralia Slovaca, 33: 499-504.

Starobová, M., 1962. Heavy minerals from the eastern part of the Magura flysch and Klippen Belt (in Czech). Geologické Práce, Zošit, 63: 47-52.

Stevens, R.E., 1944. Composition of some chromites of the Western Hemisphere. American Mineralalogist, 29: 1-34.

Stránik, Z., 1965. Geology of the Magura Flysch of the Čergov Mts. and western part of the Ondavská vrchovina hills (in Czech with German summary). Sborník Geologických Vied, Západné Karpaty, 3: 125-173.

Suggate, S.M., Hall, R., 2013. Using detrital garnet compositions to determine provenance: a new compositional database and procedure. Geological Society Special Publications, 386: 373-393.

Świdziński, H., 1961. La série de Richvalddans les Carpathes Flyscheuses. Bulletin de l'Académie Polonaise des Sciences, Série des sciences Géologiques et Géographiques, 9: 109-119.

Świerczewska, A., 2005. The interplay of the thermal and structural histories of the Magura nappe (Outer Carpathians) in Poland and Slovakia. Mineralogia Polonica, 36: 91-144.

Świerczewska, A., Tokarski, A.K., 1998. Deformation bands and the history of folding in the Magura nappe, Western Outer Carpathians (Poland). Tectonophysics, 297: 73-90.

Udubaşa, G., Hărtopanu, P., Ilinca, G., Valdman, S., 1996. The regionally metamorphosed Mn-Fe deposit at Răzoare, Preluca Mts., Romania. Romanian Journal of Mineral Deposits, 77: 3-20.

Ustaszewski, K., Schmid, S., Fügenschuh, B., Tischler, M., Kossling, E., Spakman, W., 2008. A map-view restoration of the Alpine-Carpathian-Dinaridic system for the Early Miocene. Swiss Journal of Geoscience, Supp. 1, 101: 273-294.

Van Loon, A.J.T., Mange, M.A. 2007. In situ dissolution of heavy minerals through extreme weathering, and the application of the surviving assemblages and their dissolution characteristics to correlation of Dutch and German Silver Sands. Developments in Sedimentology, 58: 189-214.

Von Eynatten, H., Gaupp, R., 1999. Provenance of Cretaceous synorogenic sandstones in the Eastern Alps: constraints from framework petrography, heavy mineral analysis, and mineral chemistry. Sedimentary Geology, 124: 81-111.

Von Eynatten, H., DunkI, I., 2012. Assessing the sediment factory: The role of single grain analysis. Earth-Science Reviews, 115: 97-120.

Vrána, S., 2011. Manganese-rich garnet-quartz rocks and gneisses in the Bohemian part of the Moldanubium Zone: lithostratigraphic markers. Journal of Geosciences, 56: 359-374.

Warchoł, M., 2007. Depositional architecture of the Magura Beds from the Siary zone, south of Gorlice (Magura Nappe, Polish 
Outer Carpathians) (in Polish with English summary). Przegląd Geologiczny, 55: 601-610.

Winkler, W., Ślączka, A., 1992. Sediment dispersaland provenance in the Silesian, Dukla and Magura flysch nappes (Outer Carpathians, Poland). Geologishe Rundschau, 81: 371-382.

Winkler, W., Ślączka, A., 1994. A Late Cretaceous to Paleogene geodynamical model for the Western Carpathians in Poland. Geologica Carpathica, 45: 71-82.

Zachar, J., Tóth, T.M., Janák, M., 2007. Kyanite eclogite xenolith from the orthogneiss terane of the Tisza Megaunit, Jánoshalma area, crystalline basement of southern Hungary. Lithos, 99 249-265.

Zhu, B., Kidd, W.S.F., Rowley, D.B., Currie, B.S., 2004. Chemical compositions and tectonic significance of chrome-rich spinels in the Tianba Flysch, southern Tibet. The Journal of Geology, 112: 417-434.

Zlatogurskaja, I.P., Akimova, K.G., Martinov, E.G., Matkovskij, I.O., Egel, L.E., 1976. Geology and metallogeny of the NW part of the Marmarosh Massif (in Slovak with English summary). Mineralia Slovaca, 8: 419-430.
Žec, B., Kaličiak, M., Konečný, V., Lexa, J., Jacko, S., jr., Baňacký, V., Karoli, S., Potfaj, M., Rakús, M., Petro, L'., Spišák, Z., Bodnár, J., Jetel, J., Boorová, D., Zlinská, A., 1997. Explanations to the geological map of the Vihorlatské and Humenské vrchy Mts. $(1: 50,000)$. Publ. D. Štúr - Geological Survey of Slovak Republic, Bratislava.

Žec, B., Gazdačko, L'., Kováčik, M., Kobulský, J., Bóna, J., Pristaš, J., Potfaj M., 2006. Geological map of the Nízke Beskydy Mts. - central part $(1: 50,000)$. Publ. Ministry of the Environment of the Slovak Republic and State Geological Institute of D. Štúr, Bratislava.

Žec, B., Gazdačko, L'., Kováčik, M., Kobulský, J., Bóna, J., Potfaj M., Pristaš, J., Žecová, K., Derco, J., Kucharič, L'., Marcin, D., Petro, L'., Zlinská, A., Siráňová, Z., Vaněková, H., Buček, S., Konečný, P., 2011. Explanations to Geological map of the Nízke Beskydy Mts. - central part $(1: 50,000)$. Publ. Ministry of the Environment of the Slovak Republic and State Geological Institute of D. Štúr, Bratislava. 